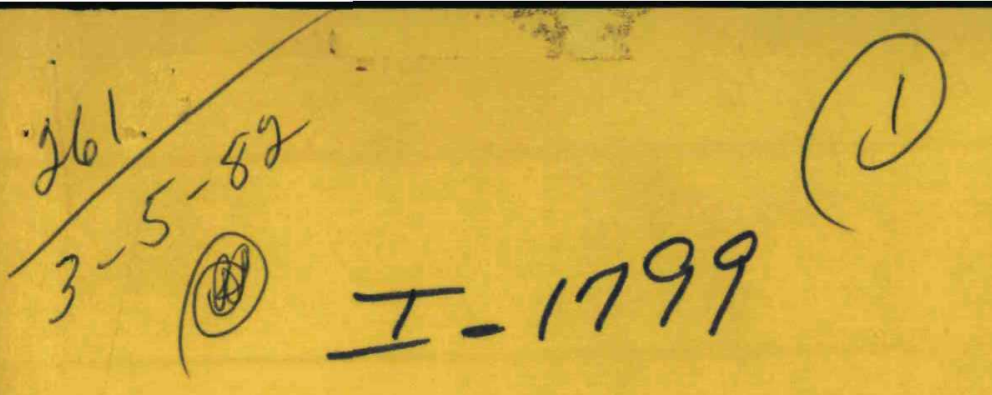

\title{
OTEC-1 Power System Test Program: Performance of One-Megawatt Heat Exchangers
}

J. J. Lorenz, D. Yung, P. A. Howard, C. B. Panchal, and F. W. Poucher

\section{DO NOT MICROFILM
COVER}

Ocean Thermal Energy Conversion Program

Argonne National Laboratory

\section{sponsored by}

U. S. Department of Energy under Contract W-31-109-Eng-38 


\section{DISCLAIMER}

This report was prepared as an account of work sponsored by an agency of the United States Government. Neither the United States Government nor any agency Thereof, nor any of their employees, makes any warranty, express or implied, or assumes any legal liability or responsibility for the accuracy, completeness, or usefulness of any information, apparatus, product, or process disclosed, or represents that its use would not infringe privately owned rights. Reference herein to any specific commercial product, process, or service by trade name, trademark, manufacturer, or otherwise does not necessarily constitute or imply its endorsement, recommendation, or favoring by the United States Government or any agency thereof. The views and opinions of authors expressed herein do not necessarily state or reflect those of the United States Government or any agency thereof. 


\section{DISCLAIMER}

Portions of this document may be illegible in electronic image products. Images are produced from the best available original document. 
The facilities of Argonne National Laboratory are owned by the United States Government. Under the terms of a contract (W-31-109-Eng-38) among the U.S. Department of Energy, Argonne Universities Association and The University of Chicago, the University employs the staff and operates the Laboratory in accordance with policies and programs formulated, approved and reviewed by the Association.

\section{MEMBERS OF ARGONNE UNIVERSITIES ASSOCIATION}

The University of Arizona

Carnegie-Mellon University

Case Western Reserve University

The University of Chicago

University of Cincinnati

Illinois Institute of Technology

University of Illinois

Indiana University

The University of Iowa

Iowa State University
The University of Kansas

Kansas State University

Loyola University of Chicago

Marquette University

The University of Michigan

Michigan State University

University of Minnesota

University of Missouri

Northwestern University

University of Notre Dame
The Ohio State University

Ohio University

The Pennsylvania State University

Purdue University

Saint Louis University

Southern Illinois University

The University of Texas at Austin

Washington University

Wayne State University

The University of Wisconsin-Madison

\section{NOTICE}

This report was prepared as an account of work sponsored by an agency of the United States Government. Neither the United States Government or any agency thereof, nor any of their employees, make any warranty, express or implied, or assume any legal liability or responsibility for the accuracy, completeness, or usefulness of any information, apparatus, product, or process disclosed, or represent that its use would not infringe privately owned rights. Reference herein to any specific commercial product, process, or service by trade name, mark, manufacturer, or otherwise, does not necessarily constitute or imply its endorsement, recommendation, or favoring by the United States Government or any agency thereof. The views and opinions of authors expressed herein do not necessarily state or reflect those of the United States Government or any agency thereof.

Printed in the United States of America

Available from

National Technical Information Service

U. S. Department of Commerce

5285 Port Royal Road

Springfield, VA 22161

NTIS price codes

Printed copy: A03

Microfiche copy: A01 
Distribution Category:

Ocean Thermal Energy

Conversion (UC-64)

ANL/OTEC-PS-1 0

ANL/OTEC-PS- -10

ARGONNE NATIONAL LABORATORY

9700 South Cass Avenue

DE82 008090

Argonne, Illinois 60439

OTEC-1 POWER SYS TEM TEST PROGRAM:

PERFORMANCE OF ONE-MEGAWATT HEAT EXCHANGERS

by

J.J. Lorenz, D. Yung, P.A. Howard

Components Technology Division

C. B. Panchal

Energy and Environmental Systems Division

F.W. Poucher

Energy Technology Engineering Center

Canoga Park, Cal i fornia

\section{NOTICE}

PORTIONS OF THIS REPORT ARE ILLEGIBLE. It

has been reproduced from the best available copy to permit the broadest possible availability.
November 1981

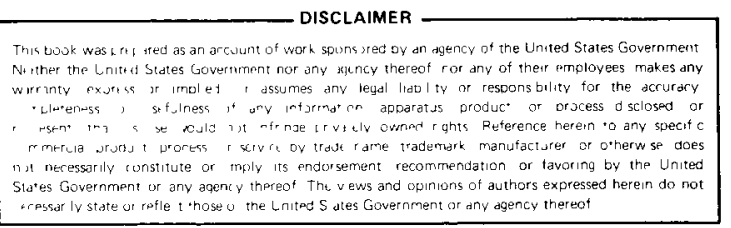

The Argonne Ocean Thermal Energy Conversion Program

is a joint effort of the

Energy and Environmental Systems Division

and Components Technology Division

sponsored by

U.S. DEPARTMENT OF ENERGY

Assistant Secretary for Conservation and Renewable Energy

Division of Solar Electric Technologies 

ABSTRACT. . . . . . . . . . . . . . . . . . . . . . . 1

1 INTRODUCTION . . . . . . . . . . . . . . . . . . . . . 1

2 OTEC-1 TEST facilitY . . . . . . . . . . . . . . . . . . . 3

3 1-MWe IEAT EXCHANGER TEST DESCRIPTION. . . . . . . . . . . . . . . 5

3.1 Test Articles... . . . . . . . . . . . . . . . . 5

3.2 Instrumentation . . . . . . . . . . . . . . . . . . . . . . . . . 7

3.3 Data Acquisition and Reduction. . . . . . . . . . . . 8

3.4 Operating Procedure . . . . . . . . . . . . . . . . . 8

4 TEST RESUlTS . . . . . . . . . . . . . . . . . . . . 10

4.1 Evaporator Tests. . . . . . . . . . . . . . . . . 10

4.1.1 Adiabatic Conditions . . . . . . . . . . . . . 10

4.1.2 Baseline Thermal Performance............. 10

4.1.3 Reflux Ratio..................... 12

4.1.4 Performance of the High Flux Surface........ . . . 14

4.1.5 Bund le-Depth and Vapor Velocity Effects. . . . . . . 15

4.1.6 Local Shel1-Side Temperatures. . . . . . . . . . . 16

4.1.7 Waterside Pressure Drop. . . . . . . . . . . . . . . 17

4.1.8 Effect of Vapor Bypass to Evaporator Sump. . . . . . . . 17

4.1.9 Effect of Ship Motion. . . . . . . . . . . . . . 18

4.2 Condenser Tests . . . . . . . . . . . . . . . . . 18

4.2.1 Adiabatic Conditions . . . . . . . . . . . . . . 18

4.2.2 Baseline Thermal Performance............. . 19

4.2.3 Performance of off-Normal Conditions . . . . . . . . 19

4.2.4 Bund le-Depth Effects . . . . . . . . . . . . . . . 19

4.2.5 Effect of Noncondensables.............. . 19

4.2.6 Waterside Pressure Drop. . . . . . . . . . . . . 20

4.2.7 Effect of Ship Motion................ 20

5 CONCLUDING REMARKS . . . . . . . . . . . . . . . . . . . 22

REFERENCES. . . . . . . . . . . . . . . . . . . . . . . . 23

ACKNOWLEDGMENTS . . . . . . . . . . . . . . . . . . . . . . . . 24

APPENDIX A: TABULATION OF INDIVIDUAL TEST RUNS . . . . . . . . . . . . 25

FIGURES

1 OTEC-1 Test P1 atform . . . . . . . . . . . . . . . . . . 3

2 Evaporator Being Lowered into the OTEC Compartment . . . . . . . . . 4

3 Evaporator Design. . . . . . . . . . . . . . . . . . . 5 
4 Condenser Design . . . . . . . . . . . . . . . . . . 6

5 OTEC-1 Power Loop Interfaces . . . . . . . . . . . . . . . 7

6 Seawater Temperatures in Evaporator Outlet Waterbox: Adiabatic Conditions .. . . . . . . . . . . . . . . . . . 11

7 Influence of Feed Rate on Evaporator Performance: Plain-Tube Bund le . . . . . . . . . . . . . . . . . . . . . 12

8 Influence of Feed Rate on Evaporator Performance: Enhanced-Tube Bund le . . . . . . . . . . . . . . . . . . . . . . 13

9 Distribution of $\mathrm{U}_{\mathrm{O}}$ in Evaporator Outlet Waterbox with Lower Bund le Deactivated ................... 16

10 Distribution of $\mathrm{U}_{\mathrm{O}}$ in Evaporator Outlet Waterbox with Lower Bund:e Partially Activated .................. 17

11 Local Evaporator Shel1-Side Temperatures . . . . . . . . . . 18

12 Se awater Temperature in Condenser Outlet Waterbox: Adiabatic Conditions . . . . . . . . . . . . . . . . . . . . . . 19

13 Condenser Performance over a Range of Heat Duties and Water Flow Rates. . . . . . . . . . . . . . . . . . . . . . 20

14 Distribution of $\mathrm{U}_{\mathrm{O}}$ in Condenser Outlet Waterbox after Purge. . . . . 21

15 Distribution of $\mathrm{v}_{\mathrm{o}}$ in Condenser Outlet Waterbox before Purge . . . . 21

\section{TABLES}

1 Heat Exchanger Operating Ranges. . . . . . . . . . . . . 10

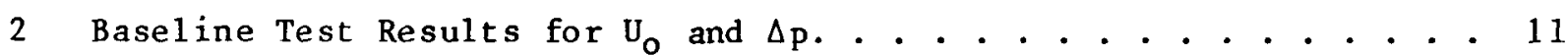


OTEC-1 POWER-SYSTEM TEST PROGRAM:

PERFORMANCE OF ONE-MEGAWATT HEAT EXCHANGERS

by

J.J. Lorenz, D. Yung, P.A. Howard, C.B. Panchal, and F.W. Poucher

\author{
ABS TRACT
}

Heat exchanger test results for the first deployment of OTEC-1 are reported. These tests were aimed at evaluating the performance of a state-of-the-art, 1-MWe titanium shell-andtube evaporator and condenser in an ocean environment. The evaporator consisted of both a plain and an enhanced (Union Carbide High Flux) tube bundle, whereas the condenser had plain tubes only. All tests with the evaporator were conducted in the sprayed-bund le mode.

Experimental results for the condenser and plain-tube portion of the evaporator were in excellent agreement with performance predictions. This result demonstrates that the thermal performance of large plain-tube heat exchangers $c$ an be predicted with a high level of confidence. However, the performance of the enhanced-tube portion of the evaporator was much lower than predicted. Evidence strongly suggested that this poor performance was attributable mainly to fouling of the High Flux surface by corrosion products consisting predominantly of hydrated aluminum oxides.

\title{
1 INTRODUCTION
}

OTEC-1 is a sea-based, Ocean Thermal Energy Conversion (OTEC) test facility constructed by the U.S. Department of Energy (DOE) for the purposes of evaluating heat exchanger performance, determining the effectiveness of biofouling countermeasures, assessing environmental impacts, and gathering ocean engineering data. A detailed test plan, developed by Argonne National Laboratory (ANL), Lawrence Berkeley Laboratory ( $L B L$ ), Energy Technology Engineering Center (ETEC), and the National Oceanographic and Atmospheric Administration (NOAA), defined the goals and priorities of the OTEC-1 first deployment test program. ${ }^{1}$ This paper focuses on the heat exchanger performance tests that were conducted as part of that program. Other parts of the test program are reported separately.

The major objective of the OTEC-1 heat exchanger test program was to evaluate the performance of a state-of-the-art, 1-MWe titanium shel1-and-tube evaporator and condenser in an ocean enviroment. The evaporator was unique in that it consisted of both a plain and an enhanced (Union Carbide High Flux) tube bundle, whereas the condenser had plain tubes only. Specifically, the OTEC-1 heat exchanger test program included: 
- Baseline performance tests to verify design predictions (evaporator and condenser);

- Variable ammonia $\left(\mathrm{NH}_{3}\right)$ feed rate tests to determine the opt imum reflux ratio (evaporator);

- Activation and deactivation tests to study the nucleation characteristics of the High Flux surface enhancement (evaporator);

- Vapor velocity tests to examine liquid entraimment and carry-over (evaporator);

- Off-normal performance tests to evaluate behavior at different heat duties and water flow rates (condenser);

- Zonal and local measurements to assess performance variations throughout the bundle (evaporator and condenser); and

- Waterside pressure drop measurements to verify design predictions (evaporator and condenser).

All tests with the evaporator were conducted in the sprayed-bundle mode. Originally, a separate series of tests with the evaporator in the flooded-bundle mode was planned, so that thermal performance in both modes (flooded and sprayed) could be compared. However, due to time and budget limitations, tests in the flooded mode were not conducted.

This report presents and discusses the OTEC-1 exchanger test results. Supplemental information on the OTEC-1 heat exchanger test program and experimental hardware $c$ an be found in Refs. 1 and 2 . 


\section{OTEC-1 TEST FACILITY}

The OTEC-1 test platform (Fig. 1) is a modified Navy T-2 tanker originally named the Chepachet and renamed the Ocean Energy Converter. Only modest structural changes were required to adapt the vessel for the OTEC-1 test program. Existing power, piping, accommodations, and other features were modified to satisfy all requirements for testing the 1-MWe he at exchangers.

The OTEC-1 test evaporator, condenser, and the balance of the test loop are instailed in an enclosed compartment (called the OTEC compartment) in the forward portion of the ship. Figure 2 shows the evaporator being lowered into the OTEC compartment, which was created by removing bulkheads between the centerline cargo tanks. All operating ammonia systems are confined to this compartment within a watertight boundary below the main deck. Ammonia storage tanks and auxiliary systems equipment are on the forward main deck above the OTEC-1 compartment.

The two test heat exchangers are positioned parallel to the ship's centerline at elevations within a few yards of the operating waterline to minimize the effects of ship motion.

Controls and instrumentation for the OTEC-1 system are located in a self-contained, air-conditioned van. The van is on a platform aft of the midship deckhouse for convenient access to OTEC-1 operating crew accommodations and the OTEC compartment.

The OTEC-1 facility has a warm and a cold seawater supply system. The cold water system consists of the cold water pipe, a sump (moon pool), a variable speed pump, the condenser, and the water discharge system. Cold

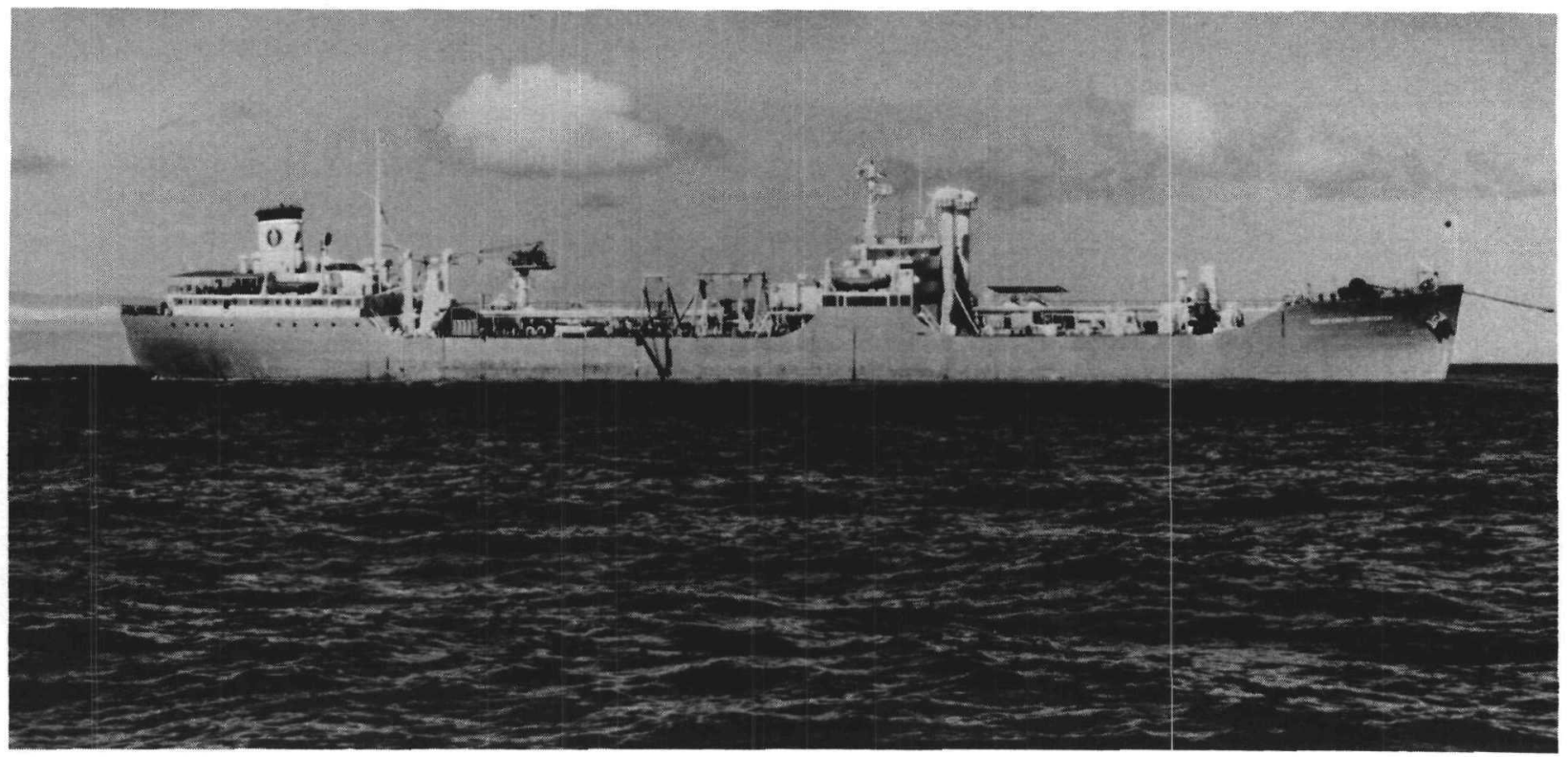

Fig. 1 OTEC-1 Test Platform 


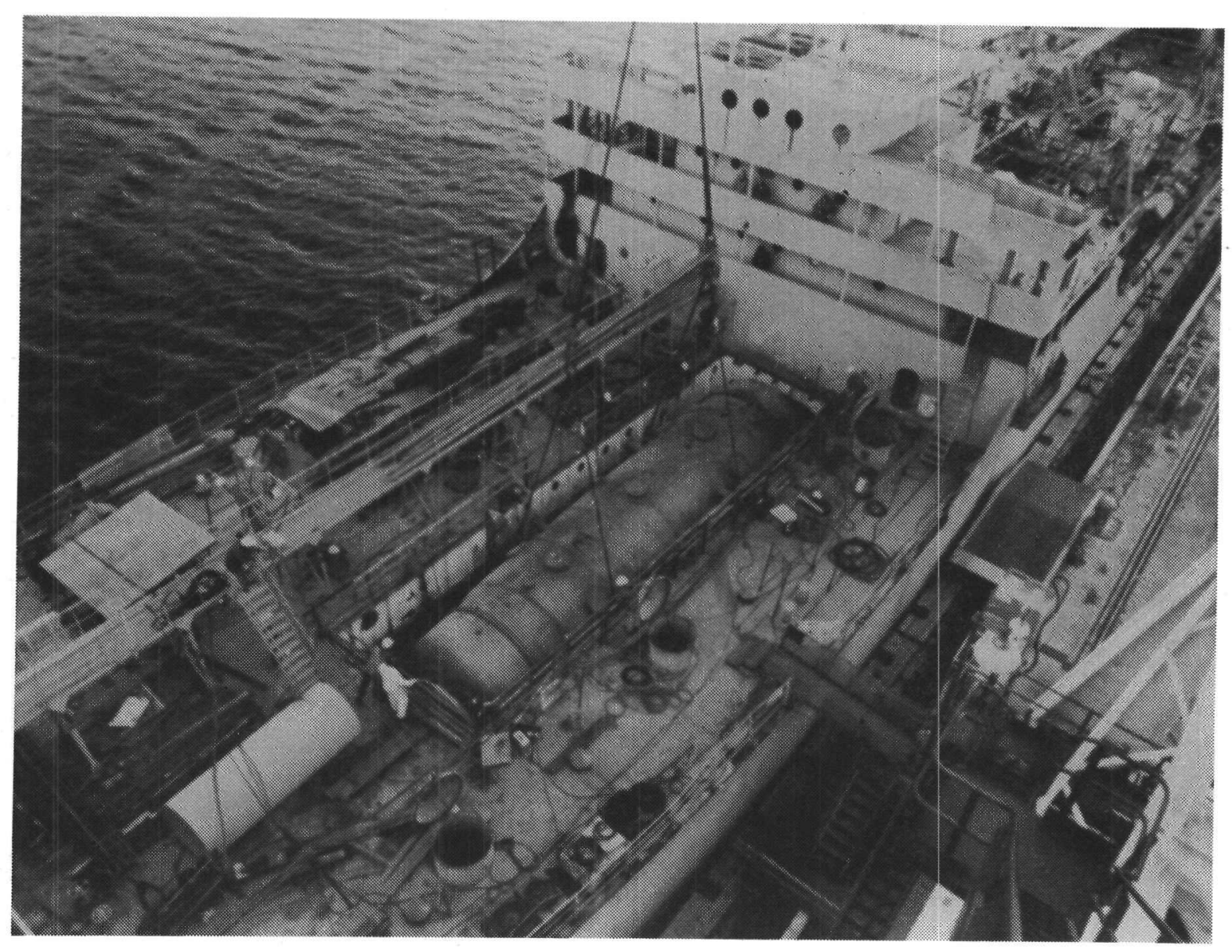

Fig. 2 Evaporator Being Lowered into the OTEC Compartment

seawater is drawn in through a screen at the bottom of a 2000-ft 1ong cold water pipe: The pipe is made up of three 48-in. diameter polyethylene pipe sections with upper and lower steel transition elements. At the upper end, the pipes merge into a single flow and attachment channel. Seawater flows upward through the cold water pipe and to the sump. From there the water is pumped through the condenser into a port wing tank where it mixes with the water effluent from the evaporator.

The warm water system consists of water intakes, a sump, a pump, the evaporator, a discharge system, and associated piping. Warm seawater is drawn through a screened opening in the hull and into the warm water sump. From there the water is pumped through the evaporator to a port wing tank, where it mixes with the condenser effluent. The mixed effluent is pumped through the discharge system into the ocean. 
3 1-MWe HEAT EXCHANGER TEST DESCRIPTION

\subsection{TEST ARTICLES}

Both the evaporator and condenser are shell-and-tube heat exchangers with seawater on the tube side and ammonia on the shell side. Geometrical features and design characteristics are shown in Figs. 3 and 4; ammonia-loop interfaces are shown in Fig. 5.

The evaporator (Fig. 3) is actually two units in one: a plain-tube upper bundle and an enhanced-tube (High Flux) lower bundle. The performance characteristics of each bundle $c$ an be measured separately. The evaporator is designed to operate in either a sprayed or flooded mode. In the flooded mode, the shell of the evaporator is filled with liquid ammonia, such that all or part of the tube bundle is submerged in a pool of ammonia. Nucleate boiling is the primary mechanism of heat transfer on the outside of the tubes.

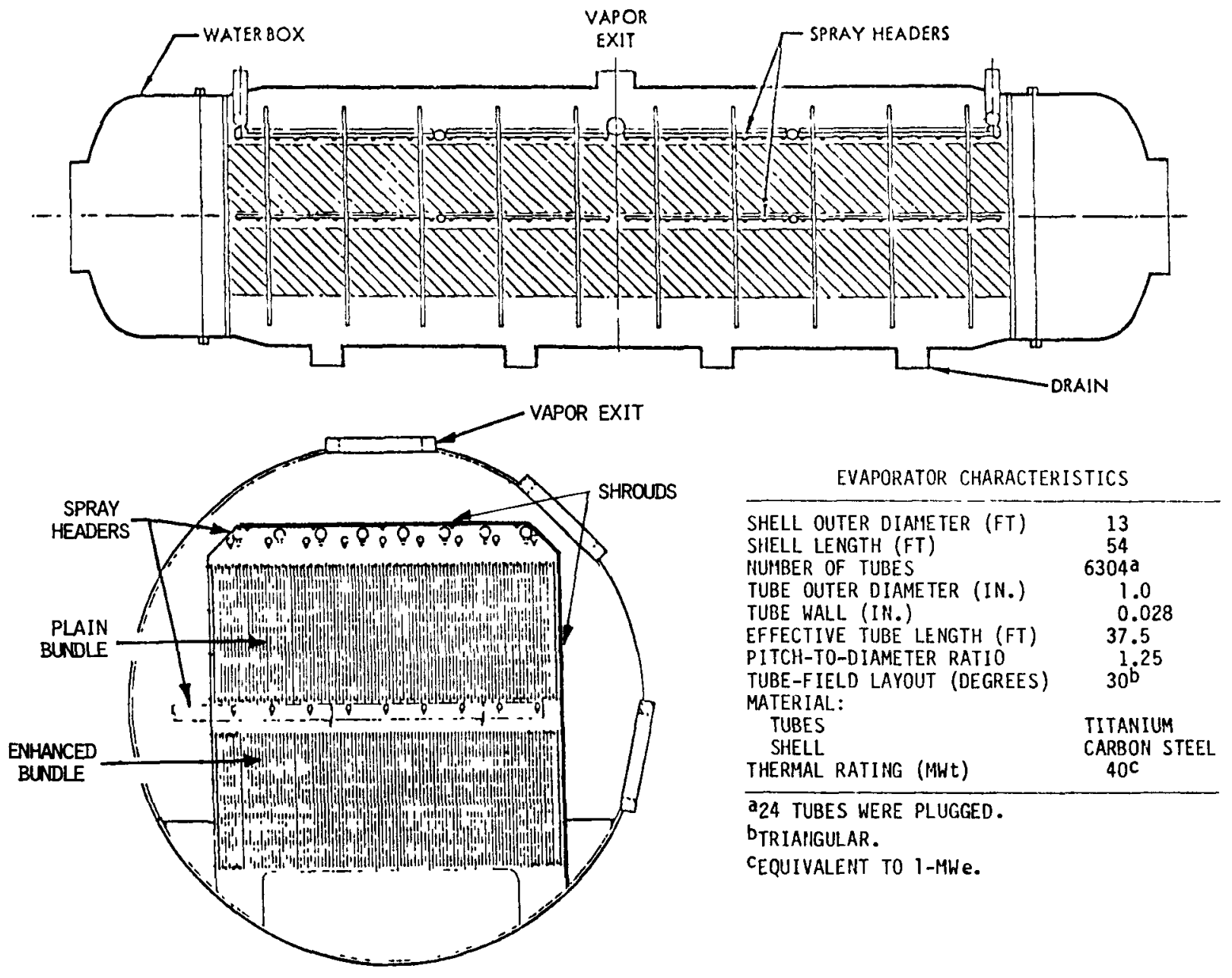

Fig. 3 Evaporator Design 

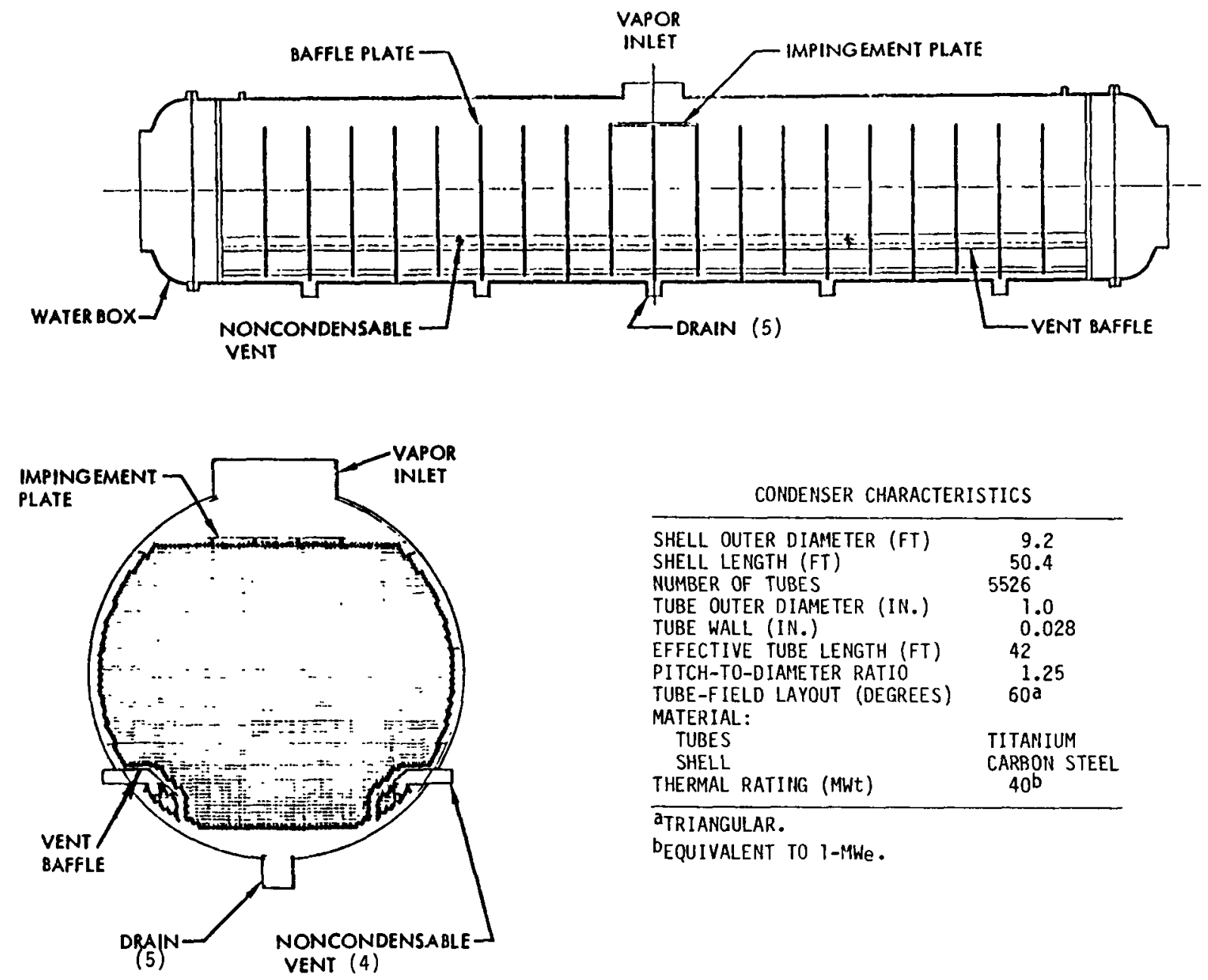

CONDENSER CHARACTERISTICS

\begin{tabular}{lc}
\hline SHELL OUTER DIAMETER (FT) & 9.2 \\
SHELL LENGTH (FT) & 50.4 \\
NUMBER OF TUBES & 5526 \\
TUBE OUTER DIAMETER (IN.) & 1.0 \\
TUBE WALL (IN.) & 0.028 \\
EFFECTIVE TUBE LENGTH (FT) & 42 \\
PITCH-TO-DIAMETER RATIO & 1.25 \\
TUBE-FIELD LAYOUT (DEGREES) & $60 \mathrm{a}$ \\
MATERIAL: & \\
TUBES & TITANIUM \\
SHELL & CARBON STEEL \\
THERMAL RATIHG (MWT) & $40 \mathrm{~b}$
\end{tabular}

aTRIANGULAR.

bEQUIVALENT TO I-MWE.

Fig. 4 Condenser Design

In the sprayed mode of operation, ammonia liquid is directed onto the tubes from nozzles situated at the top plane and mid plane of the evaporator. The top-plane feed system consists of two separate sets of nozzles (a lowpressure, high-flow set and a high-pressure, low-flow set) and the mid plane consists of a single set (high-pressure, low-flow). Thin-film evaporation is the primary mechanism of heat transfer on the outside of the plain tubes and nucleate boiling is the primary mechanism on the enhanced tubes. A side shroud plate, shown in Fig. 3, was installed to limit vapor flow to one direction only, simulating the crossflow characteristics of a 4-MWe evaporator. All tests were performed with this simulated 4-MWe configuration.

The condenser (Fig. 4) has plain tubes only. Ammonia vapor (slightly superheated) enters at the top and condenses in a filmwise manner on the tube surfaces. The condensate falls to the bottom of the shell and is collected in five drain lines, each of which has a turbine flowmeter for measuring the condensate flow rate. Noncondensable gases are removed via four vents located near the bottom of the bundle. 


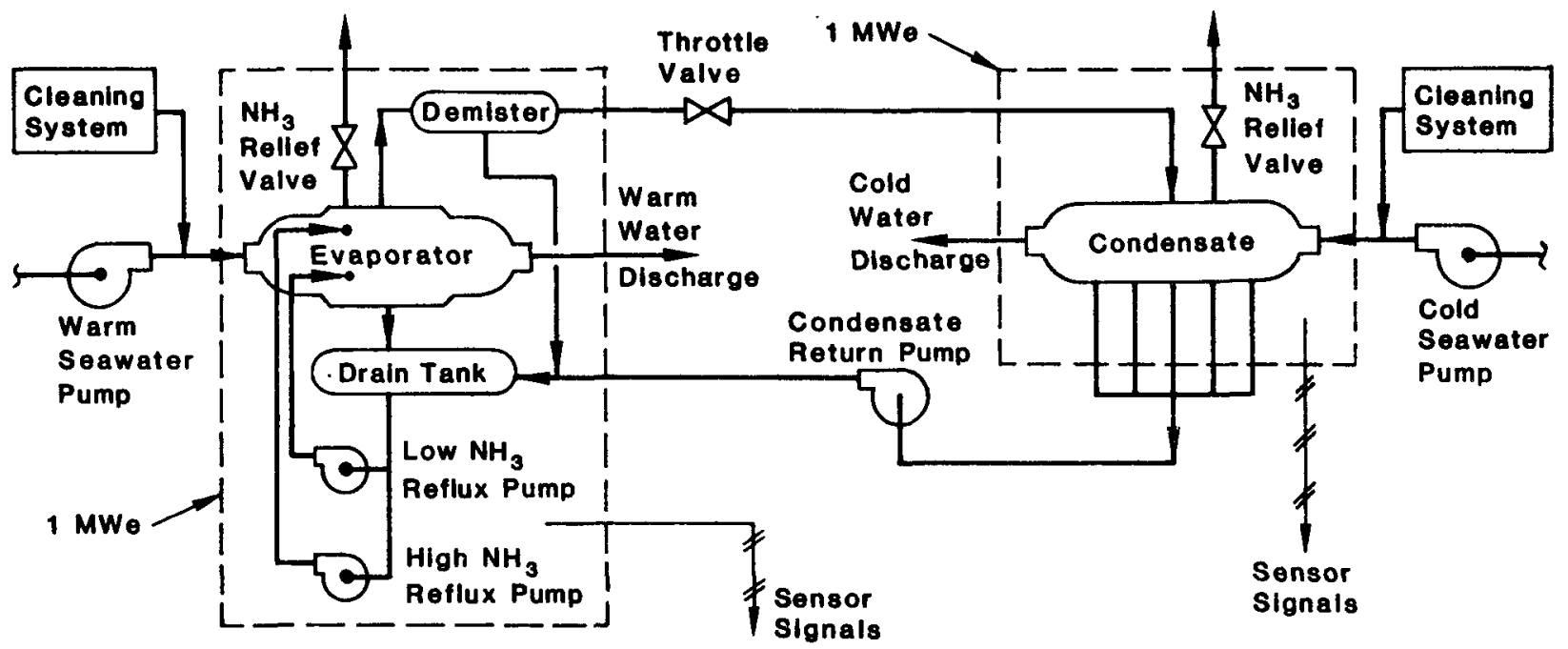

Fig. 5 OTEC-1 Power Loop Interfaces

In both heat exchangers, ammonia temperatures and pressures are measured on the shell side, and seawater temperatures and pressures are measured in the inlet and outlet waterboxes. The outlet waterbox of each heat exchanger is instrumented with a rake of Resistance Temperature Detectors (RTDs) for evaluating zonal performance over the bundle cross section. Each heat exchanger is also equipped with instrumented loops for measuring the performance of individual tubes within the bundle.

Biofouling in the heat exchangers is controlled by intermittent chlorination ( $0.4 \mathrm{ppm}$ for one hour each day) in combination with continuous Amertap (one ball every 15 minutes for each tube). Two ANL biofouling and corrosion modules are used to track the buildup of fouling in the evaporator and condenser (one module for each unit). During the first deployment, measurements with the modules yielded no evidence of heat exchanger tube-side fouling. The lack of t'be-side fouling was further inferred from the fact that the overall heat exchanger performance did not degrade with time.

\subsection{INS TRUMENTATION}

The target accuracy for measuring the overall heat transfer coefficient $\left(\mathrm{U}_{\mathrm{O}}\right)$ was $\pm 10 \%$. To achieve this, temperatures had to be measured to within $\pm 0.125^{\circ} \mathrm{F}$ and seawater flow rates to within $\pm 5 \%$ (of reading). Generally, these accuracy goals were met or surpassed. A special copper-block technique was used for end-to-end calibration of the RTDs.

Before testing began, most of the critical power loop instrumentation was fully checked out and calibrated in accordance with the OTEC-1 test plan requirements. During the test program, the bulk of the OTEC-1 instrumentation functioned satisfactorily, enabling acquisition of most of the originally planned test data. However, a number of instrumentation failures resulted in losses of data. These failures included: (1) the turbine 
flowmeters and RTDs in the condenser drain lines, resulting in a loss of data on the axial condensate flow profile; (2) the sonic flowmeter in the demister return line, resulting in a loss of data on liquid carry-over; (3) the instrumented loop flowmeters and RTDs in both the evaporator and condenser, resulting in a loss of data on individual tube performance; (4) pressure transducers in the condenser inlet and outlet waterboxes, resulting in a loss of the pressure-drop data for comparison with design predictions; and (5) the sonic flowmeters in both the warm and cold seawater systems, resulting in a loss of data needed for heat balance checks.

In the case of the seawater sonic flowmeters, it was discovered that the transmission signals were being attenuated by bubbles in both the warm and cold seawater systems. Corrective actions were taken in an attempt to eliminate the bubbles. As a result, the population of bubbles was reduced dramatically, but not enough to mitigate the attenuation problem. Later, two other sonic flowmeters were tried: a transmission type having a higher signal strength and a Doppler type. Results with these meters, although encouraging, were judged to be unsatisfactory. After exploring a number of alternative means for measuring flow, it was decided simply to calculate the warm and cold seawater flow rates from heat duty measurements on the ammonia side -- i.e., by equating the ammonia-side heat duty (measured) to the waterside heat duty (unknown) and solving for the seawater flow rate. This technique is expected to yield a flow rate accuracy of $\pm 5 \%$, but $c$ an be employed on $1 y$ when the ammonia system is operational and heat is being transferred. The main disadvantage of not having a direct seawater flow $r$ ate measurement is that no independent waterside/ammonia-side heat balance checks $c$ an be made.

\subsection{DATA ACQUISITION AND REDUCTION}

The OTEC-1 test facility has a minicomputer-based data acquisition system (DAS) that $c$ an sample and record all channels of data, apply calibration and correction factors to these data, and provide real-time computation and display (with hard copy) of selected calculated quantities and sensor readings in engineering units. Data $c$ an be recorded on disk and tape at independently selected rates. During first deployment testing, data were generally recorded on tape at a rate of one sample per minute. Original data tapes were analyzed on board in real time and duplicate tapes were sent to ANL for more detailed evaluation of the test results.

The data reduction program is based largely on the equations developed in the OTEC-1 test plan.1 Only a few minor changes had to be made to the original program. For example, heat duty is now calculated solely on the basis of ammonia-side measurements. Also, in the prediction of $U_{0}$ for the lower (enhanced) portion of the evaporator, account is now taken of the fact that only $90 \%$ of the active tube length consists of the High Flux enhancement.

\subsection{OPERATING PROCEDURE}

The normal start-up procedure for the ammonia system is as follows (seawater system al ready running): 
1. Purge power loop with nitrogen until residual air-toammonia ratio is diluted well below explosive limit;

2. Transfer ammonia into evaporator sump;

3. Close throttle valve $(\mathrm{V}-111)$ located in vapor line between evaporator and condenser;

4. Start ammonia reflux pump to initiate ammonia spray;

5. As vapor is generated and evaporator pressure begins to rise, open V-lll to allow vapor to flow to condenser;

6. When level of condensate rises in central condenser drain line, start condensate return pump;

7. Monitor ammonia levels in the condensate drain line and evaporator sump; and

8. Adjust valve $v-111$ as required to achieve desired heat duty and allow system to stabilize.

The evaporator pressure, and hence heat duty, is controlled by the setting of valve V-111. The ammonia loop control system is capable of maintaining either constant heat duty or constant pressure in the evaporator. Generally, either mode of control is acceptable. However, for the reflux ratio tests, it was convenient to hold the evaporator pressure constant and allow the heat duty to vary.

Following system start-up, steady-state conditions were generally attained in about two hours unless the sea state was unusually high. During rough weather, it was difficult to maintain steady operation of the ammonia system, mainly because of sloshing of ammonia in the sumps. Also, cavitation of the ammonia reflux pump occurred when the ammonia level in the evaporator sump (drain tank) was low.

When a change was made from an established test condition to a new (slightly different) test condition, steady operation at the new condition was usually reached in less than 30 minutes. All tests were conducted for a minimum of 30 minutes. Typically, the duration of a given test ranged from 30 minutes to 2 hours. In a special test to study long-term activation of the enhanced surface, the duration was extended to 35 hours. 


\section{TEST RESULTS}

A total of 95 tests were conducted during 370 hours of ammonia system operation over a three-month period, January through March 1981. Operating ranges are shown in Table 1 and a tabulation of individual runs is given in Appendix A. Tests 1-29 were regarded as shakedown runs for debugging the system and gaining operational experience. During these initial shakedown tests, the water content of the ammonia was unacceptably high $(\approx 0.9 \%$ by weight); by distillation, the water content was reduced to a tolerable level ( $<0.4 \%$ by weight) before Tests $30-95$ were conducted.

\subsection{EVAPORATOR TESTS}

\subsubsection{Adiabatic Conditions}

To establish confidence in the seawater temperature measurements, the inlet and outlet average waterbox temperatures were compared under adiabatic conditions (i.e., with the ammonia system shut down), as shown in Fig. 6. These temperatures were in excellent agreement. Also, the individual exit RTD readings agreed within the calibration tolerance of $\pm 0.125^{\circ} \mathrm{F}$, except for two RTDs near the center, which read $77.09^{\circ} \mathrm{F}$ and $77.59^{\circ} \mathrm{F}$ (see Fig. 6).

\subsubsection{Baseline Thermal Performance}

Baseline test results are presented in Table 2. The measured value of $U_{o}$ for the plain-tube portion of the evaporator is in perfect agreement with the prediction. Although this perfect agreement is somewhat fortuitous (because the absolute accuracy of the measured $U_{0}$ is only $\pm 10 \%$ ), it shows that the thermal performance of the plain-tube, sprayed-bundle evaporator can be predicted with a high level of confidence. The predicted $U_{0}$ value for the plain-tube bundle was based on a waterside coefficient of $1330 \mathrm{Btu} / \mathrm{hr} \cdot \mathrm{ft}{ }^{2} \cdot{ }^{\circ} \mathrm{F}$ from the Petukhov-Popov correlation ${ }^{3}$ and an ammonia-side coefficient of 1000 $\mathrm{Btu} / \mathrm{hr} \cdot \mathrm{ft}^{2}{ }^{\circ} \mathrm{F}$ from Conti's single-tube data.4 Zero fouling was assumed.

Table 1 Heat Exchanger Operating Ranges

\begin{tabular}{|c|c|c|}
\hline Parameter & Ev aporator & Condenser \\
\hline Heat duty (MWt) & $14-46$ & $14-46$ \\
\hline Se awa ter f1 ow (gpm) & $57,000-91,000$ & $32,000-67,000$ \\
\hline Se awater temperature $\left({ }^{\circ} \mathrm{F}\right)$ & $76-78$ & $41-43$ \\
\hline Ammonia feed $\mathrm{rate}^{\mathrm{a}}(\mathrm{gpm})$ & $400-3700$ & NA \\
\hline $\begin{array}{l}\text { Ammonia shell-side parameters } \\
\text { Pressure (psia) } \\
\text { Saturation temperature }\left({ }^{\circ} \mathrm{F}\right)\end{array}$ & $\begin{array}{c}128.8-133.4 \\
70-72\end{array}$ & $\begin{array}{c}82.7-99.7 \\
46-56\end{array}$ \\
\hline
\end{tabular}




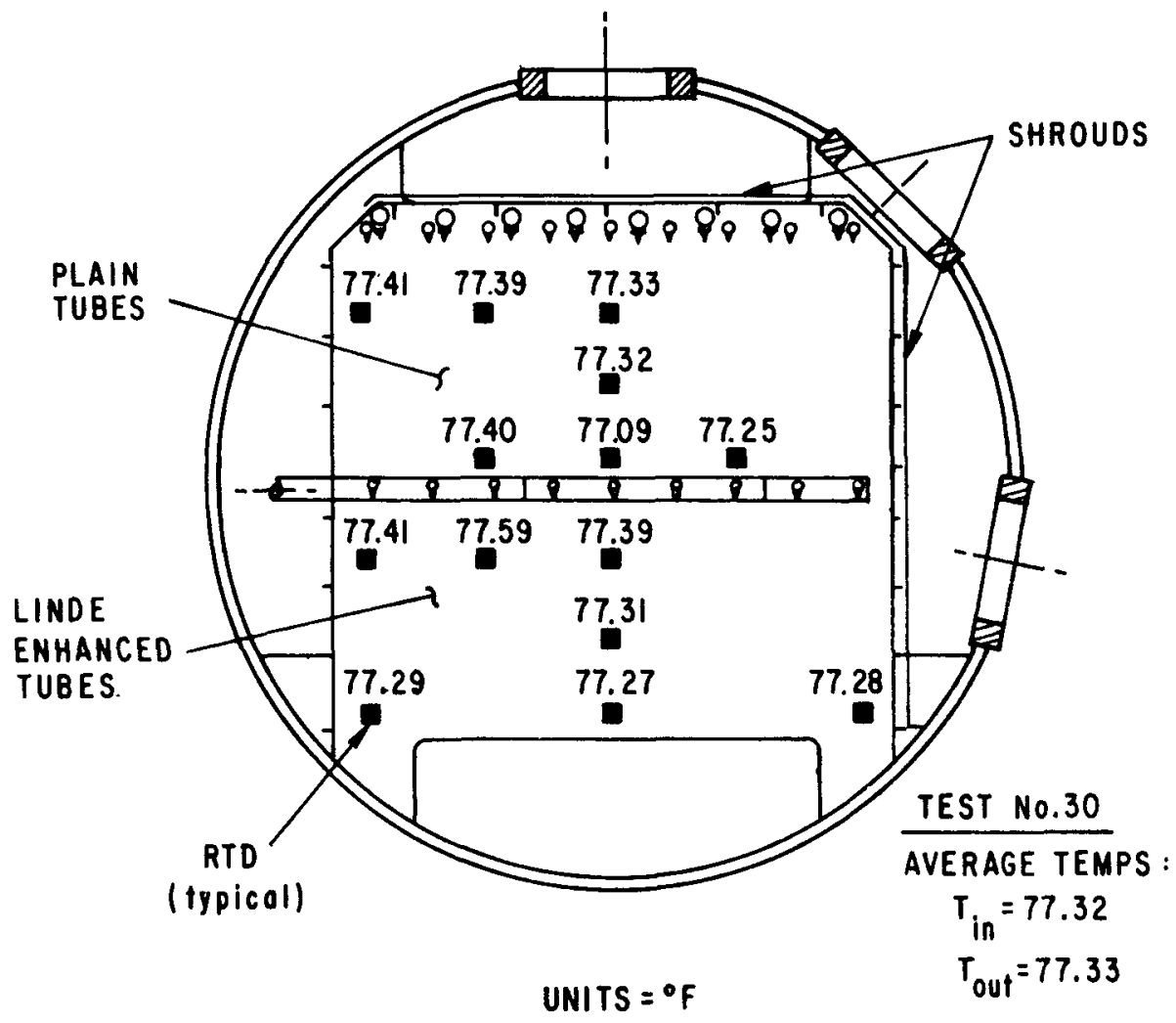

EVAPORATOR OUTLET WATERBOX

Fig. 6 Seawater Temperatures in Evaporator Outlet Waterbox: Adiabatic Conditions

Table 2 Baseline Test Results for $U_{0}$ and $\Delta \mathrm{p}^{a}$

\begin{tabular}{|c|c|c|c|c|}
\hline \multirow[b]{2}{*}{ Heat Exchanger } & \multicolumn{2}{|c|}{$\mathrm{U}_{\mathrm{O}}\left(\mathrm{Btu} / \mathrm{hr} \cdot \mathrm{ft} \mathrm{t}^{2}{ }^{\circ} \mathrm{F}\right)$} & \multicolumn{2}{|c|}{$\Delta p(p s i)$} \\
\hline & Me asur ed b & Predicted & Me asured b & Predicted \\
\hline \multicolumn{5}{|l|}{ Evaporator } \\
\hline Plain bund le & 490 & 490 & 2.7 & 2.5 \\
\hline Enhanced bund le & $600^{c}$ & 735 & 2.7 & 2.5 \\
\hline Condenser & 480 & 490 & $d$ & 2.9 \\
\hline
\end{tabular}

$a_{U_{0}}=$ overall heat transfer coefficient; $\Delta p=$ waterside pressure drop through heat exchanger; nominal conditions were: heat duty $=40 \mathrm{MWt}$; ammonia feed rate $=3300 \mathrm{gpm}$; warm water flow rate $=83,000 \mathrm{gpm}$; cold water feed rate $=67,000 \mathrm{gpm}$.

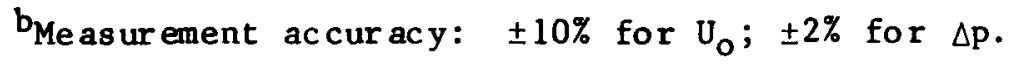

CPartially activated (see Fig. 6).

dPressure transducer out of calibration. 
Table 2 shows that the measured performance of the enhanced-tube portion of the evaporator is considerably lower than predicted. This poor performance is thought to be caused mainly by fouling of the High Flux surface by corrosion products, as will be discussed further in Sec. 4.1.4. The predicted $U_{0}$ value for the enhanced bundle was based on the same waterside coefficient as was used for the plain-tube bundle, and on an ammonia-side coefficient of $3800 \mathrm{Btu} / \mathrm{hr} \cdot \mathrm{ft}{ }^{2} \cdot{ }^{\circ} \mathrm{F}$ from ANL experiments with a small-scale Union Carbide sprayed bundle.5 (Originally, ANL reported an amonia-side coefficient of $4600 \mathrm{Btu} / \mathrm{hr} \cdot \mathrm{ft}{ }^{2}{ }^{\circ} \mathrm{F}$, but later revised that value to $3800 \mathrm{Btu} /$ $\mathrm{hr} \cdot \mathrm{ft} \mathrm{t}^{\circ} \mathrm{F}$ based on an improved Wilson plot procedure.) The predictions accounted for the fact that $10 \%$ of the active tube length did not have High F1ux.

\subsubsection{Reflux Ratio}

The power consumed by the ammonia reflux pump represents a parasitic loss in the system; therefore, it is important to optimize (minimize) the feed rate. Figure 7 gives the results for the plain bundle. As the feed rate is reduced, $U_{0}$ remains constant until a critical (minimum) feed rate of 1000 $\mathrm{gpm}$ is reached. Below this critical feed rate, $U_{0}$ drops sharply as film breakdown and dryout occur on the lowermost tubes in the bundle. At this critical condition, the critical local flow $r$ ate on the lowermost tubes is about $45 \mathrm{lbm} / \mathrm{hr} \cdot \mathrm{ft}$. This critical flow rate is an important design parameter because it defines the operating limit of any plain-tube spray evaporator for

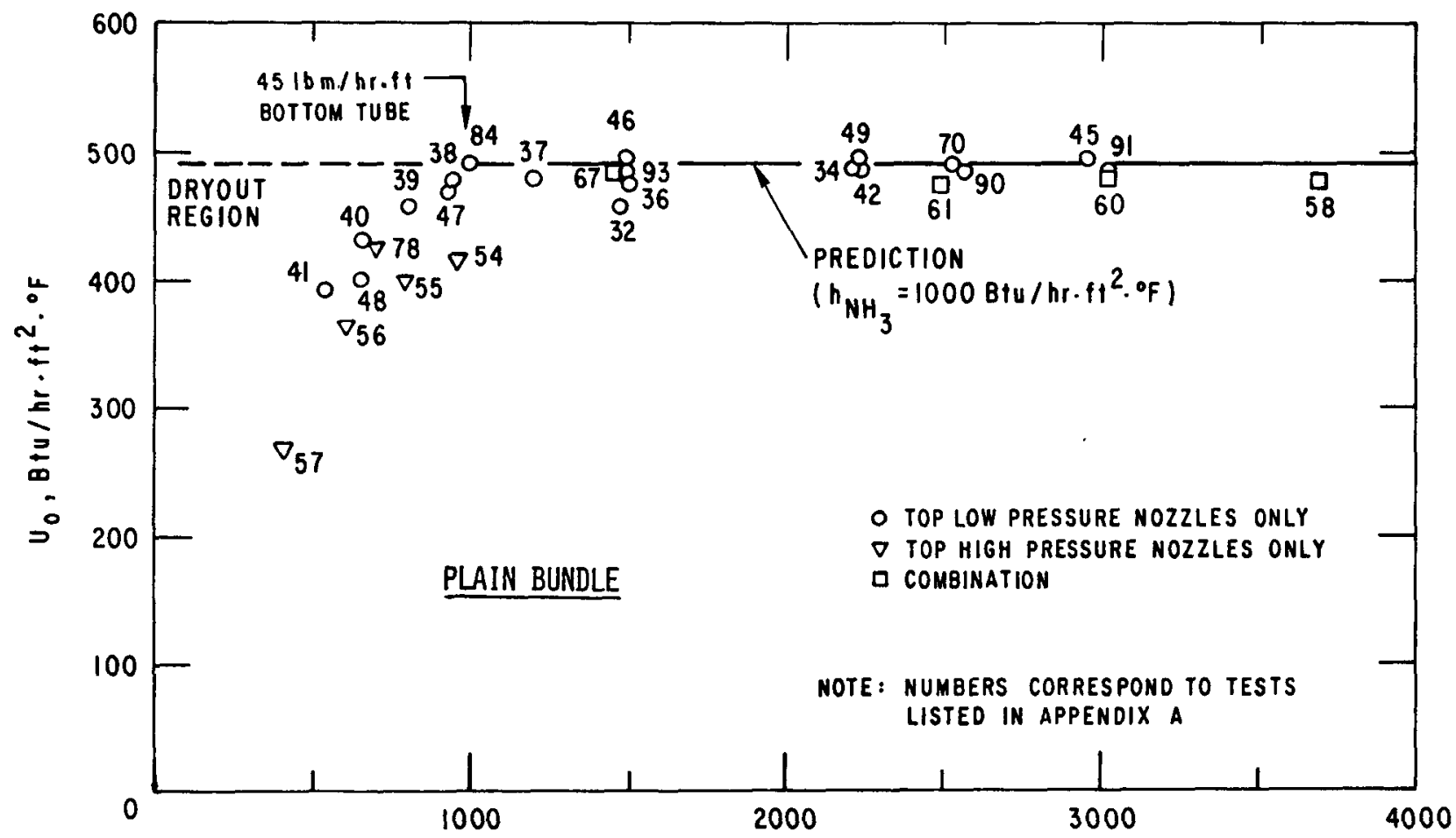

AMMONIA FEEO RATE, gPM

Fig. 7 Influence of Feed Rate on Evaporator Performance: Plain-Tube Bundle 
OTEC application: it represents the minimum flow that must be supplied to the lowermost tubes to ensure complete wetting and, hence, optimum performance of the evaporator. As expected, this minimum flow rate of $45 \mathrm{lbm} / \mathrm{hr} \cdot \mathrm{ft}$ for plain tubes is higher than the value of $201 \mathrm{bm} / \mathrm{hr} \cdot \mathrm{ft}$ obtained in tests at ANL with High Flux enhanced tubes because the plain tubes are not as easily wetted and the film breaks down sooner.

Figure 7 shows that evaporator performance is not strongly affected by the spray system used, whether it be top low-pressure nozzles only, top high-pressure only, or a combination of the two.

Results for the enhanced bundle are presented in Fig. 8. The term "effective ammonia feed" refers to the net amount of ammonia liquid reaching the lower bundle. Depending on the method of system start-up (see Sec. 4.1.4), the data fell on either the upper or lower "curve." The lower curve (deactivated) is similar to the performance of the smooth tube in Fig. 7. Actually, the enhanced-tube performance of $430 \mathrm{Btu} / \mathrm{hr} \cdot \mathrm{ft}{ }^{2} \cdot{ }^{\circ} \mathrm{F}$ is somewhat poorer than the plain-tube performance of $490 \mathrm{Btu} / \mathrm{hr} \cdot \mathrm{ft}^{2} \cdot{ }^{\circ} \mathrm{F}$ because the deactivated High Flux surface acts as a sponge and holds a stagnant insulating layer of ammonia liquid. An ammonia layer of about 1 mil would account for the difference.

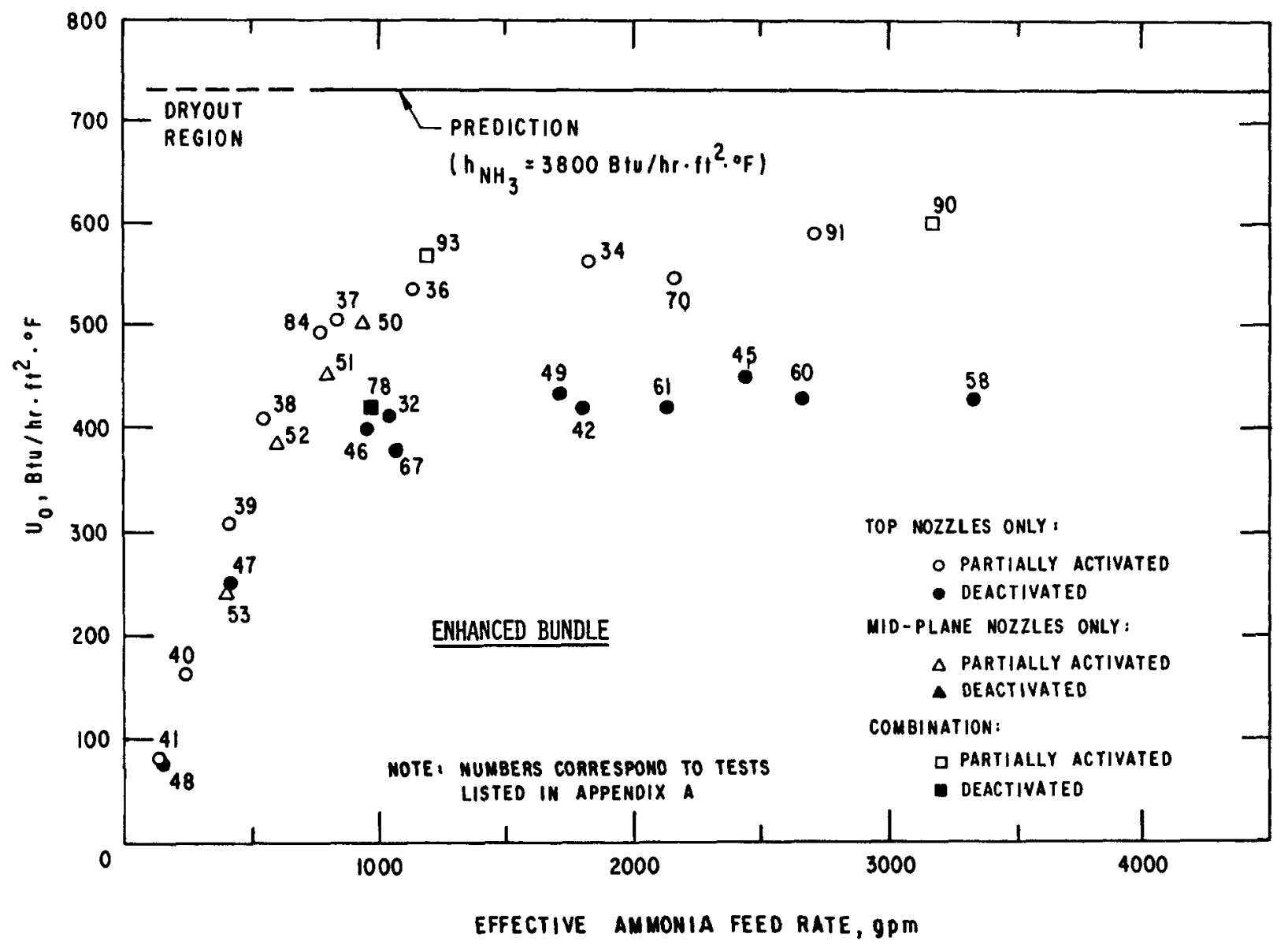

Fig. 8 Influence of Feed Rate on Evaporator Peformance: Enhanced-Tube Bund le 
When the enhanced surface was partially activated (by changing the method of start-up), the performance improved, but remained well below the predicted level. Based on a measured value of $\mathrm{U}_{\mathrm{o}}$ equal to $600 \mathrm{Btu} / \mathrm{hr} \cdot \mathrm{ft} 2{ }^{\circ} \mathrm{F}$, the ammonia-side coefficient was calculated to be $1720 \mathrm{Btu} / \mathrm{hr} \cdot \mathrm{ft}^{2} \cdot{ }^{\circ} \mathrm{F}$, which is only $45 \%$ of the predicted value of $3800 \mathrm{Btu} / \mathrm{hr} \cdot \mathrm{ft}{ }^{2} \cdot{ }^{\circ} \mathrm{F}$. Reasons for the poor performance of the enhanced surface are discussed in the next section.

An interesting hysteresis effect was observed when the surface was partially activated. The upper curve in Fig. 8 could not be retraced after the feed rate was reduced below about $500 \mathrm{gpm}$ and then increased. Instead, the data fell on the lower curve when the feed rate was increased, indicating that the surface had become deactivated during operation at the lower feed rates.

\subsubsection{Performance of the High Flux Surface}

Unless special start-up and operating procedures were employed, the enhanced tubes invariably behaved as plain tubes ( $i . e$. , the lower curve in Fig. 8). Three different procedures to activate the nucleation sites were tried: (1) initially drying out the tubes by shutting off the ammonia feed and opening the throttle valve between the evaporator and condenser for a specified length of time; (2) increasing the excess superheat for nucleation by temporarily reducing the evaporator pressure while maintaining the ammonia feed; and (3) pulling a partial vacuum ( $15 \mathrm{inHg}$ ) for an extended period to evaporate volatile liquid (e.g., water) occluded in the pores (unfortunately, a sufficiently large vacuum pump was not available to pull a harder vacuum). of these three procedures, the dryout operation proved to be the most successful, but it still only partially improved the heat transfer performance of the enhanced surfaces, which remained well below the predicted level, even on a local basis. See Sec. 4.1 .5 for a discussion of local variations of Uo throughout the bundle.

Evidence strongly suggested that the poor performance of the enhanced bundle was attributable mainly to fouling of the High Flux surface. Union Carbide Corp. examined a section of High Flux tubing removed from the OTEC-1 evaporator and found that the tube was fouled with a layer of white crystalline material identified by $X-r$ ay diffraction analysis as bayerite or hydrated beta aluminum hydroxide $\mathrm{Al}(\mathrm{OH})_{3}$, with a small amount of iron oxide. ${ }^{2}$ These corrosion deposits were embedded in the porous surface and, hence, destroyed the nucleation sites. Union Carbide is trying to identify an effective cleaning method for rejuvenating the surface.

Union Carbide tested a section of the fouled tubing in the as-received condition and compared it with an original control tube (from the 1979 production run), which was retested at the same time.7 Water was passed through the inside of the tube and freon-11 was boiled on the outside. Because the tests were conducted with freon instead of ammonia, the relative behavior was more important than absolute coefficients. The test results indicated a substantial degradation of performance of the fouled tube relative to the original (clean) tube. The ratio of boiling coefficients (fouled/clean) was 0.38 , which compares favorably with the ratio of 0.45 deduced from the OTEC-1 test data (see Sec. 4.1.3). These results support the hypothesis that the poor performance observed on board OTEC-1 was due mainly to fouling. 
Union Carbide's metal lurgy department suspects that the corrosion of the High Flux enhancement was produced by prolonged exposure of the tubes to a warm, humid marine atmosphere. An alternate possibility is a chemical reaction between aluminum and ammonia in the presence of small amounts of seawater. A complete analysis of the problem must take into account the entire history of conditions to which the heat exchanger was exposed throughout its lifetime - from initial fabrication through final deployment and testing. In any case, one thing is certain: fouling of the High Flux surface must have occurred prior to the start-up of ammonia system operation because the poor performance was detected at the very out set of testing - there was no further degradation with time.

In addition to fouling, there were less-important factors that could have contributed to the poor performance of the High Flux tubes. A post-test inspection revealed widespread plugging of the mid-plane spray nozzles. This should not, however, have had a major effect on heat exchanger performance for two reasons: (1) the mid-plane nozzles provided only make-up feed to the lower bundle, and (2) the top-plane nozzles, which provided the primary feed to both bundles, must have been functioning properly, as evidenced by the excellent performance of the upper bundle. The post-test inspection also revealed oily patches on portions of the tube surfaces. Moreover, oil was present on the tube sheets, tube support baffles, and inside walls of the evaporator she11. Presumably, this was ammonia pump lubricating oil that leaked past the pump seal and into the ammonia system.

\subsubsection{Bundle-Depth and Vapor Velocity Effects}

Figure 9 shows the zonal distribution of $U_{0}$ in the exit waterbox of the evaporator for a run in which the lower (enhanced) half was deactivated. The $U_{0}$ values are fairly uniform within each half of the evaporator. The uniformity in the vertical direction indicates that liquid-loading effects are smal 1; the uniformity in the horizontal direction reveals that vapor velocity effects are insignificant. The unimportance of vapor velocity also was observed during earlier shakedown runs in which $U_{0}$ was generally found to be unaffected when the heat duty, and hence vapor velocity, was reduced to $60 \%$ of nominal. This result was expected on the basis of ANL's analysis 6 showing that a crossflow velocity of at least $5 \mathrm{ft} / \mathrm{sec}$ is required to deflect the falling film. The maximum crossflow in the evaporator was only $3 \mathrm{ft} / \mathrm{sec}$ in the gaps between the outermost tubes. Although the vapor velocity was too low to cause gross entrainment and liquid redistribution within the bundle, there may have been some carry-over of small droplets produced by fracture and splashing as the ammonia liquid spray impinged on the uppermost tubes. Unfortunately, a failure of the sonic flowneter in the phase-separator (demister) return line precluded a quantitative assessment of liquid carry-over.

Figure 10 shows the zonal distribution of $U_{0}$ for a case where the lower bund le is partially activated. As in Fig. 9, the distribution of $U_{o}$ in the upper bundle is fairly uniform. However, the $U_{0}$ values in the lower bundle range from a high value of $651 \mathrm{Btu} / \mathrm{hr} \cdot \mathrm{ft}^{2 .{ }^{\circ} \mathrm{F}}$ in the center to a low of 521 $B t u / h r \cdot f t^{2} \cdot{ }^{\circ} \mathrm{F}$ in the upper left hand corner. This variation is considered to be caused not by vapor velocity or bund le-depth effects, but by differences in the nucleation characteristics of the tubes resulting from varying degrees of fouling throughout the bundle. 


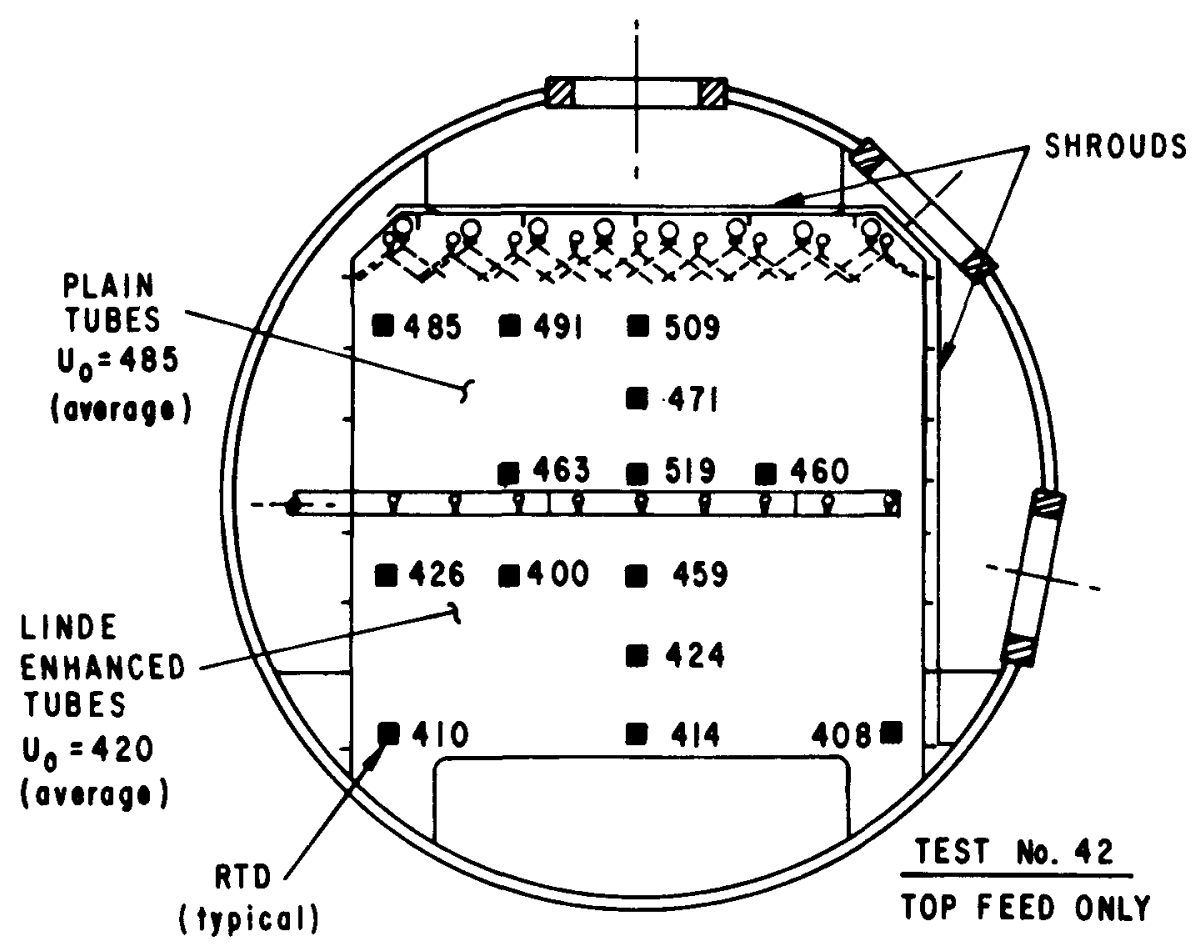

UNITS $=8 \mathrm{tu} / \mathrm{hr} \cdot f \mathrm{ft}^{2} \cdot{ }^{\circ} \mathrm{F}$

\section{EVAPORATOR OUTLET WATERBOX}

Fig. 9 Distribution of $\mathrm{U}_{\mathrm{o}}$ in Evaporator Outlet Waterbox with Lower Bund le Deactivated

It was originally intended to study vapor velocity effects by conducting a separate series of tests with the side shroud removed (1-MWe configuration) and making a comparison with results obtained with the side shroud in place (4-MWe configuration). The vapor velocity in the 1-MWe configuration would be half that in the 4-MWe configuration. However, since tests with the latter configuration clearly showed an absence of vapor velocity effects, separate tests with the 1-MWe configuration -- which has an even lower vapor velocity -- were deemed unnecessary.

\subsubsection{Local She11-Side Temperatures}

The evaporator shell-side temperature distribution was found to be un iform both axially and circumferentially (see Fig. 11). The measured shel1-side temperatures were in excellent agreement with the saturation temperature calculated at the shell-side pressure. Among other things, the existence of a saturated vapor state indicates that the ammonia is pure. In the early shakedown tests with water in the ammonia, the state of the vapor was not saturated, but superheated. 


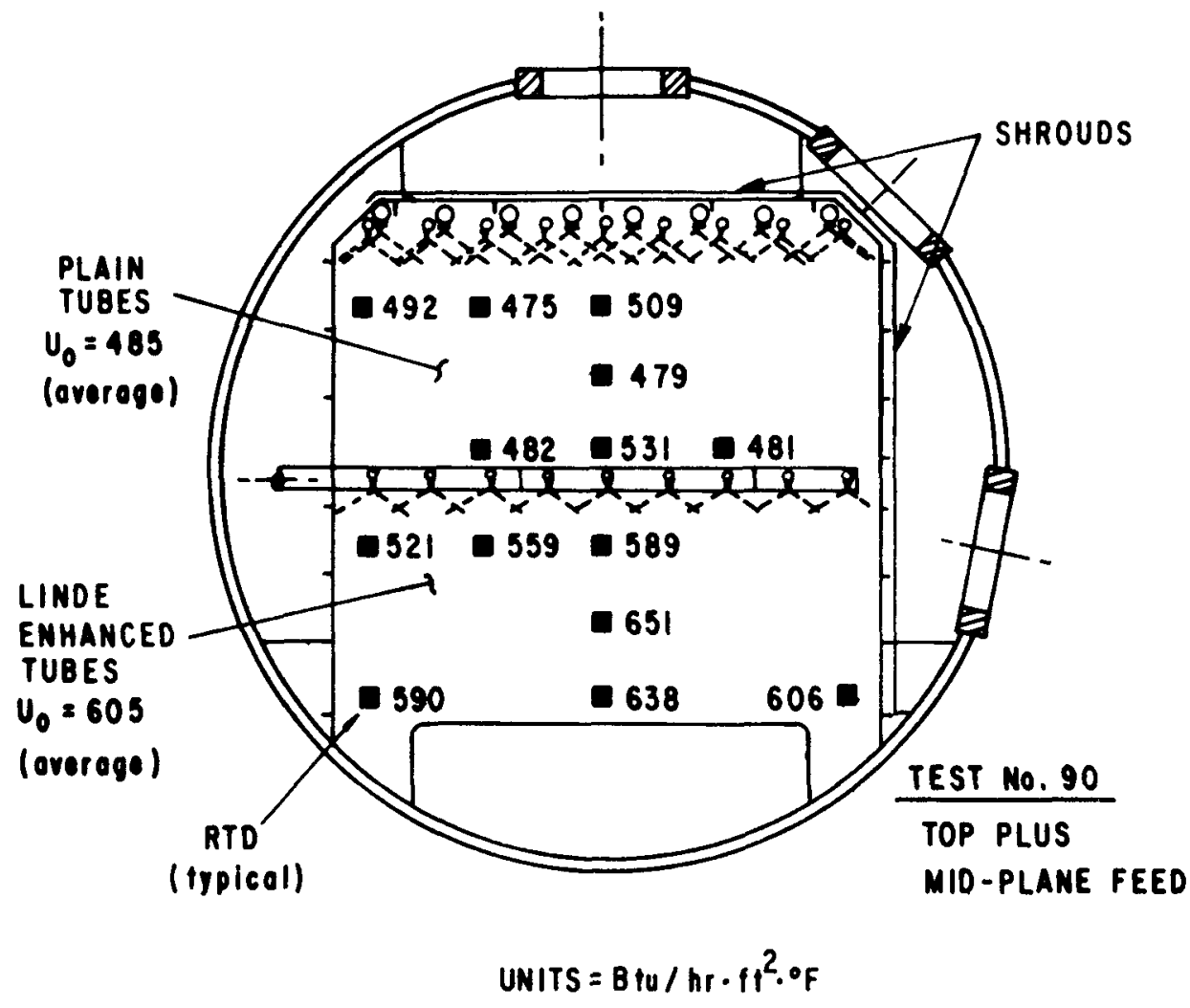

EVAPORATOR OUTLET WATERBOX

Fig. 10 Distribution of $\mathrm{U}_{0}$ in Evaporator Outlet Waterbox with Lower Bundle Partially Activated

\subsubsection{Waterside Pressure Drop}

The measured pressure drop between the inlet and outlet waterbox agreed favorably with predictions, as shown in Table 2.

\subsubsection{Effect of Vapor Bypass to Evaporator Sump}

During operation, it was found that the temperature of the ammonia feed was nearly equal to the saturation temperature in the evaporator, suggesting that some ammonia vapor from the evaporator must have been flowing downward through the drain 1 ine and condensing directly into the evaporator sump (drain tank). An energy balance on the sump revealed that this bypass flow amounted to about $5 \%$ of the total vapor generated within the evaporator. The original data reduction program did not account for the bypass flow and calculated the evaporator heat duty solely on the basis of the vapor exiting at the top of the evaporator (as measured by a Venturi flowmeter in the vapor line). Thus, the evaporator heat duty calculation was $5 \%$ low. Also, the $U_{0}$ value and the seawater flow rate were $5 \%$ low since they were both calculated from the heat duty. The results given in this report are based on the original data reduction program and hence do not reflect the $5 \%$ correction. Nevertheless, the primary conclusions drawn from the data remain the same. 


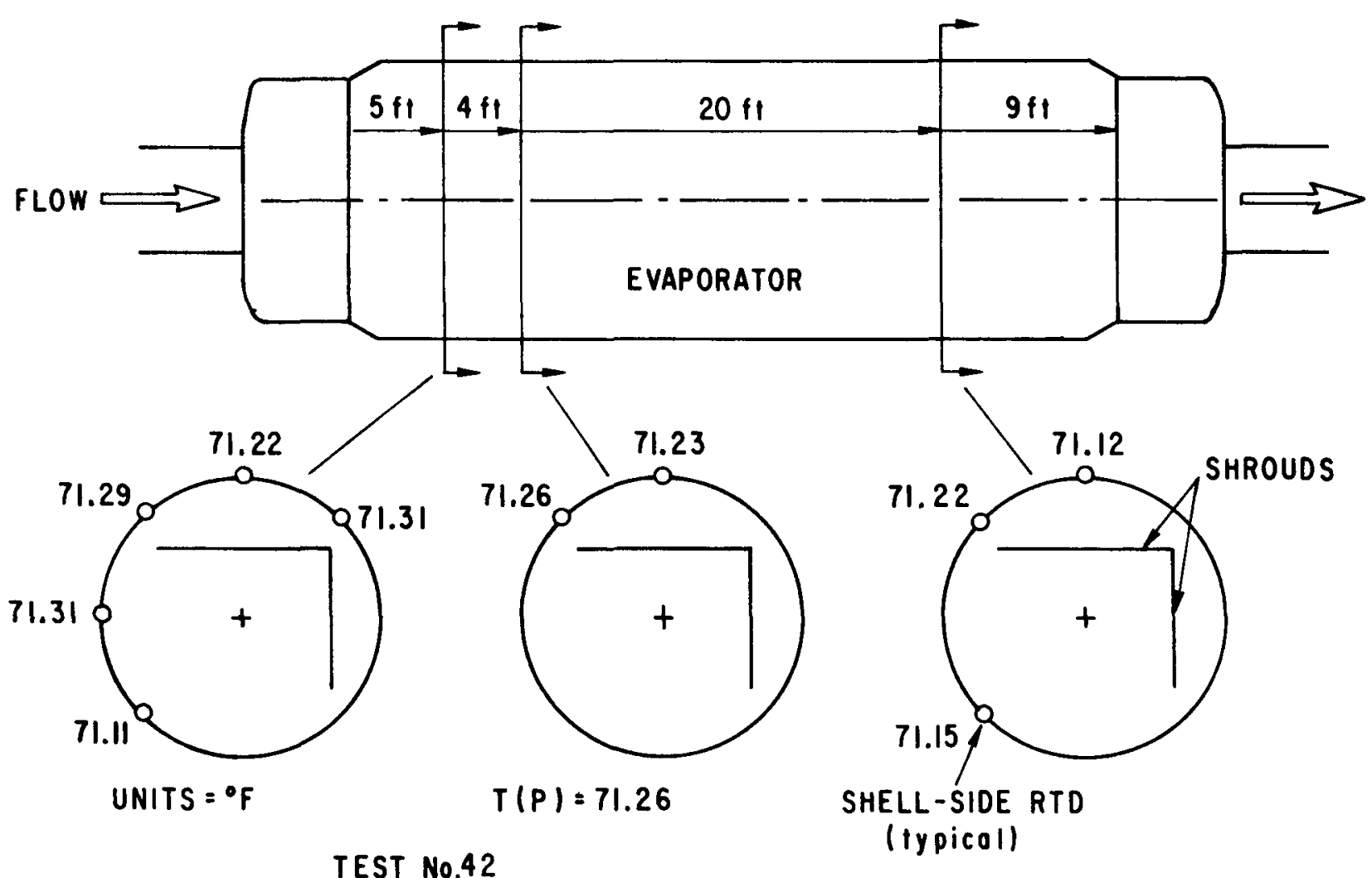

Fig. 11 Local Evaporator Shell-Side Temperatures

Vapor bypass is undesirable and probably $c$ an be prevented by reducing the diameter of the evaporator drain lines.

\subsubsection{Effect of Ship Motion}

There was no apparent influence of ship motion on evaporator performance: data taken during high sea states were similar to data taken during calm weather. However, maintaining steady operation of the ammonia system was difficult during high sea states. Also, cavitation of the reflux pump was experienced when the ammonia level was 1 ow.

\subsection{CONDE NSER TESTS}

\subsubsection{Adiabatic Conditions}

As in the case of the evaporator, the condenser inlet and outlet average waterbox temperatures were in excellent agreement, and the individual outlet waterbox RTDs agreed to within the calibration tolerance of $\pm 0.125^{\circ} \mathrm{F}$ (see Fig. 12). 


\subsubsection{Baseline Thermal Performance}

Baseline results for the condenser are given in Table 2. Typically, ammonia vapor entered the condenser superheated by about $6^{\circ} \mathrm{F}$ and ammonia condensate left the condenser subcooled by about $1^{\circ} \mathrm{F}$. Here, as in the case of the plain-tube evaporator, the thermal performance is predictable to a high level of accuracy. The predicted $U_{0}$ value was calculated on the basis of a waterside coefficient of $980 \mathrm{Btu} / \mathrm{hr} \cdot \mathrm{ft}^{2}{ }^{\circ} \mathrm{F}$ from the Petukhov-Popov correlation and an ammoniaside coefficient of $1428 \mathrm{Btu} / \mathrm{hr} \cdot \mathrm{ft}^{2}{ }^{\circ} \mathrm{F}$ in accordance with the original thermal design calculations of C.F. Braun and Co.

\subsubsection{Performance at Off-Normal Conditions}

Figure 13 shows condenser thermal performance over a range of heat duties (from $18 \mathrm{MWt}$ to $47 \mathrm{MWt}$ ) and flow rates from $32,000 \mathrm{gpm}$ to $67,000 \mathrm{gpm})$. Over the entire parametric range, predictions are in excellent agreement with the measured $U_{0}$ values. The data exhibit a negligibly small dependence on heat flux, suggesting that the condenser was free of noncondensables. In tests conducted prior to purging, the $U_{o} v a l u e$ of the condenser was observed to drop markedly at low heat dut ies.

\subsubsection{Bundle-Depth Effects}

The distribution of $U_{0}$ in the exit waterbox is presented in Fig. 14. As expected, the zonal $U_{0}$ values are fairly uniform in a given horizontal plane, but decrease with bundle depth as a result of condensate inundation.

\subsubsection{Effect of Noncondensable Gases}

Figure 15 shows the distribution of $U_{0}$ in the exit waterbox before purging. Comparison of Figs. 14 and 15 shows that noncondensable gases tend to build up in the lower half of the condenser. Generally, it was found that several three-minute purges were adequate to remove noncondensable gases. 


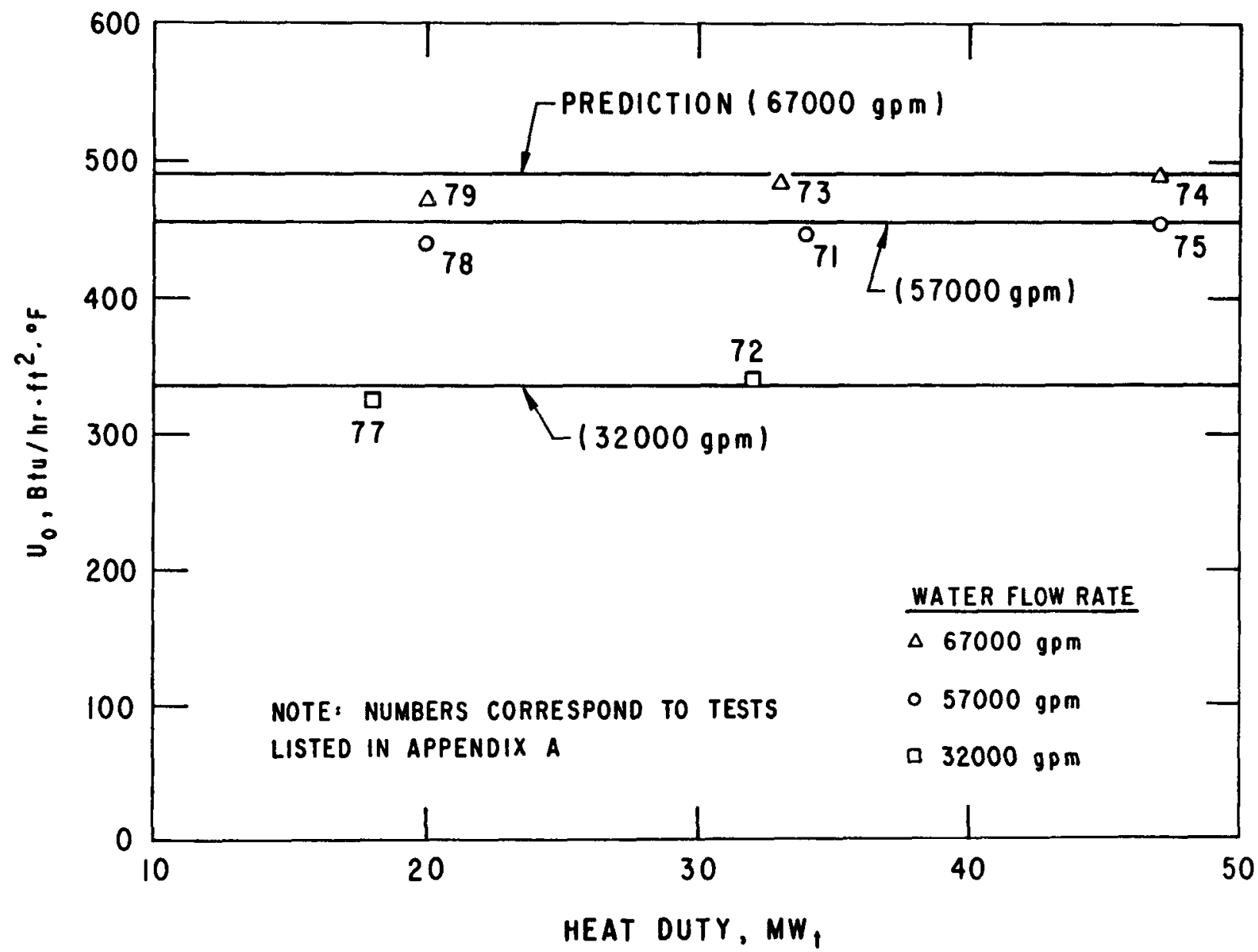

Fig. 13 Condenser Performance over a Range of Heat Duties and Water Flow Rates

\subsubsection{Waterside Pressure Drop}

Due to a faulty (out-of-calibration) waterbox pressure transducer, no valid measurements were obtained for comparison with predictions (see Table 2).

\subsubsection{Effect of Ship Motion}

As in the case of the evaporator, ship motion had no discernible effect on performance, but caused some unsteadiness in the operation of the ammonia system. 


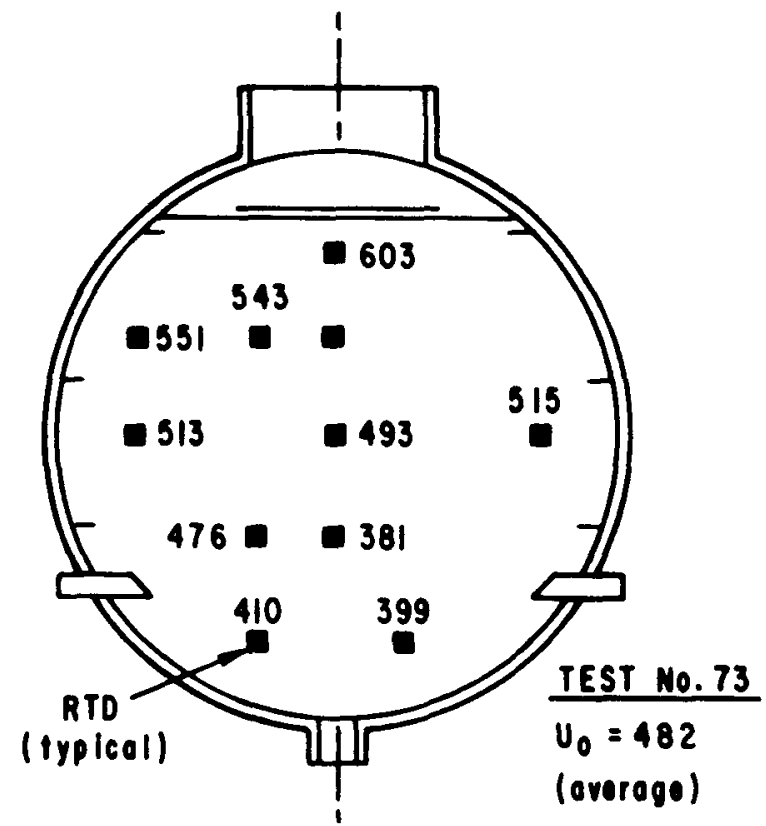

UNITS $=B f u / h r \cdot f f^{2} \cdot{ }^{\circ} F$

Fig. 14 Distribution of $U_{o}$ in Condenser Outlet Waterbox after Purge

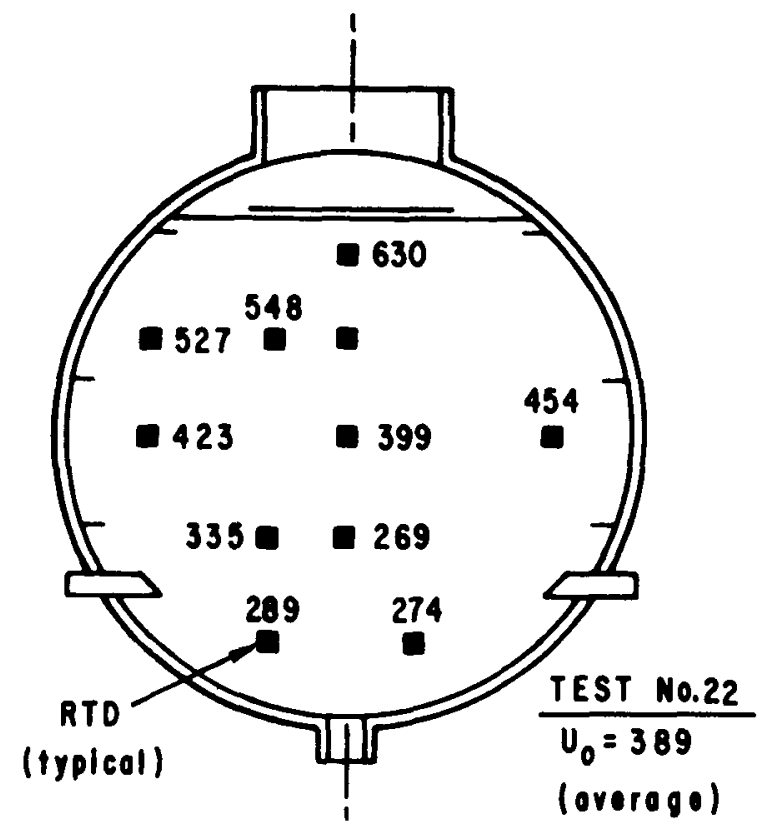

UNITS $=B+U / h r \cdot f t^{2} \cdot \bullet^{\circ}$

\section{CONDENSER OUTLET WATERBOX}

Fig. 15 Distribution of $U_{0}$ in Condenser Outlet Waterbox before Purge 


\section{CONCLUDING REMARKS}

During the first deployment of OTEC-1, most of the instrumentation and power loop components functioned satisfactorily, enabling the bulk of the originally planned test data to be acquired. There were, however, a number of instrumentation problems that resulted in a loss of certain data. Nevertheless, most of the essential OTEC-1 test objectives were satisfied.

Experimental results for the condenser and plain-tube portion of the evaporator were found to be in excellent agreement with performance predictions. This result demonstrates that the thermal performance of 1 arge plaintube heat exchangers can be predicted with a high level of confidence. On the other hand, the performance of the enhanced-tube portion of the evaporator was much lower than predicted. Evidence strongly suggested that this poor performance was attributable mainly to fouling of the High Flux surface by corrosion products consisting predominantly of hydrated aluminum oxides. 


\section{REFERENCES}

1. OTEC-1 Power Systems Test Program: Test Plan for First Deployment, Argonne National Laboratory Report ANL/OTEC-PS-6 (March 1980).

2. Snyder, J.E., et al., 1-MWe Heat Exchangers for OTEC - Status Report, June 1978, Proc. Sixth Ocean Thermal Energy Conversion Conf., Washington, D.C. (June 1979).

3. Petukhov, B.S., Heat Transfer and Friction in Turbulent Pipe Flow With Variable Physical Properties, Advances in Heat Transfer, Vol. 6 (1970).

4. Conti, R.J., Experimental Investigation of Horizontal-Tube Ammonia Film Evaporators with Small Temperature Differentials, Proc. Fifth Ocean Thermal Energy Conversion Conf., Miami Beach, F1a. (Feb. 1978).

5. Hillis, et al., OTEC Performance Tests of the Union Carbide SprayedBundle Evaporator, Argonne National Laboratory Report ANL/OTEC-PS-3 (May 1979).

6. Yung, D., J.J. Lorenz, and E.N. Ganic, Vapor/Liquid Interaction and Entrainment in Falling Film Evaporators, ASME Journal of Heat Transfer, Vol. 102, No. 1 (Feb 1980).

7. O'Neil1, P.S., Union Carbide Corp., personal communication (May 1981). 


\section{ACKNOWLEDGMENTS}

The authors wish to acknowledge the following individuals for their special contributions to the OTEC-1 heat exchanger test program: $F$. Davis (ANL), an ammonia system expert, for playing a major role in developing start-up and operating procedures and in resolving operational problems throughout the course of testing; N. Sather and A. Thomas (ANL) for providing managerial support and participating in the planning of tests; $R$. Niemann (ANL) and P.P. Pandolfini (APL) for assistance in compliance verification activities and shakedown testing; A. Klein, R. Hoshide, and the entire OTEC crew for valuable contributions in all aspects of test operations, P. O'Neill (Union Carbide Corp.) for conducting single-tube tests to resolve the poor performance of the High Flux enhancement; and K. Bell (OSU), J.E. Snyder (TRW), and K. Read (U.S. Naval Academy) for many helpful comments and suggestions. We also wish to make a general acknowledgment of the contributions of all individuals affiliated with participating organizations: DOE, ANL, ETEC, TRW, TRACOR, GMDI, Union Carbide Corp., and many others. This report was prepared with the editorial assistance of $P$. Chen and was typed by B. O'Meara. 
APPENDIX A

TABULATION OF INDIVI DUAL TEST RUNS 
Appendix A: Tabulation of Individual Test Runs

\begin{tabular}{|c|c|c|c|c|c|c|c|c|c|c|}
\hline \multirow[b]{3}{*}{ Test } & \multirow[b]{3}{*}{ Description } & \multirow{3}{*}{$\begin{array}{l}\text { Heat } \\
\text { Duty } \\
\text { (Mwt) }\end{array}$} & \multirow{3}{*}{$\begin{array}{l}\text { Warm } \\
\text { Water } \\
\text { Flow Rate } \\
(\mathrm{gpm})\end{array}$} & \multicolumn{3}{|c|}{ Ammonia Feed Rate (gpm) } & \multicolumn{2}{|c|}{$\mathrm{U}_{\mathrm{O}}\left(\mathrm{Btu} / \mathrm{hr} \cdot \mathrm{ft}{ }^{\left.2 \cdot{ }^{\circ} \mathrm{F}\right)}\right.$} & \multirow{3}{*}{$\begin{array}{l}\text { F1 ow Rate } \\
(\mathrm{gpm})\end{array}$} & \multirow{3}{*}{$\left(B t u / h r^{\cdot} \cdot f t^{2} \cdot{ }^{\circ} F\right)$} \\
\hline & & & & \multicolumn{2}{|c|}{ Top Nozzles } & \multirow{2}{*}{$\begin{array}{l}\text { Mid- } \\
\text { Plane }\end{array}$} & \multirow{2}{*}{$\begin{array}{l}\text { Plain } \\
\text { (upper) }\end{array}$} & \multirow{2}{*}{$\begin{array}{l}\text { Enhanced } \\
(\text { lower })\end{array}$} & & \\
\hline & & & & Low-Pressure & High-Pressure & & & & & \\
\hline $1-29$ & $\begin{array}{l}\text { Shaked own } \\
\text { test s }\end{array}$ & & & & & & & & & \\
\hline 30 & $\begin{array}{l}\text { Di atillation } \\
\text { \& evacuation }\end{array}$ & 0 & 78,000 & 0 & 0 & 0 & N/A & $\mathbf{N} / \mathbf{A}$ & 55,000 & N/A \\
\hline 31 & $\begin{array}{l}\text { Surface } \\
\text { conditioning }\end{array}$ & 0 & 78,000 & $\begin{array}{c}0 \text { for dry } \\
1500 \text { for wet }\end{array}$ & 0 & 0 & $N / A$ & $\mathrm{~N} / \mathrm{A}$ & 55,000 & $\mathbf{N} / \mathbf{A}$ \\
\hline 32 & Basel ine & 39 & 78,000 & 1500 & 0 & $\mathbf{0}$ & 460 & 410 & 55,000 & 450 \\
\hline 33 & $\begin{array}{l}\text { Surface } \\
\text { conditioning }\end{array}$ & 0 & 82,000 & 0 & 0 & 0 & N/A & $\mathbf{N} / \mathbf{A}$ & 55,000 & $N / A$ \\
\hline 34 & Baseline & 37 & 82,000 & 2200 & 0 & 0 & 485 & 565 & 55,000 & 455 \\
\hline 35 & Deluge & 35 & 82,000 & 2200 & 0 & 0 & 480 & 560 & 55,000 & 455 \\
\hline $\begin{array}{l}36 \\
37 \\
38 \\
39 \\
40 \\
41\end{array}$ & $\begin{array}{l}\text { Retlux ratio } \\
\text { tests }\end{array}$ & $\begin{array}{l}35 \\
35 \\
\\
32 \\
28 \\
24\end{array}$ & $\begin{array}{l}82,000 \\
82,000 \\
82,000 \\
82,000 \\
82,000 \\
82,000\end{array}$ & $\begin{array}{r}1500 \\
1200 \\
950 \\
800 \\
660 \\
550\end{array}$ & $\begin{array}{l}0 \\
0 \\
0 \\
0 \\
0 \\
0\end{array}$ & $\begin{array}{l}0 \\
0 \\
0 \\
0 \\
0 \\
0\end{array}$ & $\begin{array}{l}475 \\
480 \\
475 \\
460 \\
430 \\
390\end{array}$ & $\begin{array}{r}535 \\
505 \\
410 \\
310 \\
165 \\
80\end{array}$ & $\begin{array}{l}55,000 \\
55,000 \\
55,000 \\
55,000 \\
55,000 \\
55,000\end{array}$ & $\begin{array}{l}450 \\
455 \\
455 \\
455 \\
450 \\
450\end{array}$ \\
\hline 42 & Baseline & 35 & 82,000 & 2200 & 0 & 0 & 485 & 420 & 55,000 & 450 \\
\hline 43 & Reflux test & 31 & 82,000 & 950 & 0 & 0 & $\mathbf{a}$ & $\mathbf{a}$ & 55,000 & 445 \\
\hline 44 & $\begin{array}{l}\text { Surface } \\
\text { conditioning }\end{array}$ & 0 & 82,000 & $\begin{array}{l}1500 \text { for wet } \\
0 \text { for dry }\end{array}$ & 0 & 0 & $N / A$ & N/A & 55,000 & $\mathbf{N} / \mathbf{A}$ \\
\hline $\begin{array}{l}45 \\
45 \\
47 \\
48 \\
49\end{array}$ & $\begin{array}{l}\text { Reflux ratio } \\
\text { tests }\end{array}$ & $\begin{array}{l}46 \\
45 \\
39 \\
29 \\
45\end{array}$ & $\begin{array}{l}85,000 \\
85,000 \\
85,000 \\
85,000 \\
85,000\end{array}$ & $\begin{array}{r}3000 \\
1500 \\
950 \\
660 \\
2200\end{array}$ & $\begin{array}{l}0 \\
0 \\
0 \\
0 \\
0\end{array}$ & $\begin{array}{l}0 \\
0 \\
0 \\
0 \\
0\end{array}$ & $\begin{array}{l}490 \\
490 \\
470 \\
400 \\
490\end{array}$ & $\begin{array}{r}450 \\
395 \\
250 \\
75 \\
435\end{array}$ & $\begin{array}{l}55,000 \\
55,000 \\
55,000 \\
55,000 \\
55,000\end{array}$ & $\begin{array}{l}445 \\
450 \\
455 \\
455 \\
450\end{array}$ \\
\hline
\end{tabular}


Appendix A: Tabulation of Individual Test Runs (Cont'd)

\begin{tabular}{|c|c|c|c|c|c|c|c|c|c|c|}
\hline \multirow[b]{3}{*}{ Test } & \multirow[b]{3}{*}{ Description } & \multirow{3}{*}{$\begin{array}{l}\text { Heat } \\
\text { Duty } \\
\text { (MWt) }\end{array}$} & \multirow{3}{*}{$\begin{array}{l}\text { Warm } \\
\text { Water } \\
\text { Fl ow Rate } \\
\text { (gpm) }\end{array}$} & \multicolumn{3}{|c|}{ Ammonia Feed Rate (gpm) } & \multicolumn{2}{|c|}{$U_{0}\left(B t u / h r \cdot f t^{2} \cdot{ }^{\circ} F\right)$} & \multirow{3}{*}{$\begin{array}{l}\text { Flow Rate } \\
(\mathrm{gpm})\end{array}$} & \multirow{3}{*}{$\left(\mathrm{Btu} / \mathrm{hr} \cdot \mathrm{ft}^{\left.\mathrm{U}^{2} \cdot{ }^{\circ} \mathrm{F}\right)}\right.$} \\
\hline & & & & \multicolumn{2}{|c|}{ Top Nozzles } & \multirow{2}{*}{$\begin{array}{l}\text { Mid- } \\
\text { Plane }\end{array}$} & \multirow{2}{*}{$\begin{array}{c}\text { Plain } \\
\text { (upper) }\end{array}$} & \multirow{2}{*}{$\begin{array}{r}\text { Enhanced } \\
\text { (lower) }\end{array}$} & & \\
\hline & & & & Low-Pressure & High-Pressure & & & & & \\
\hline 50 & Reflux ratio & 18 & 83,000 & 0 & 0 & 930 & $\mathbf{N} / \mathbf{A}$ & 500 & 55,000 & 420 \\
\hline 51 & test s: mid- & 19 & 83,000 & 0 & 0 & 795 & $\mathbf{N} / \mathbf{A}$ & 450 & 55,000 & 420 \\
\hline 52 & plane feed & 17 & 83,000 & 0 & 0 & 600 & $\mathbf{N} / \mathbf{A}$ & 385 & 55,000 & 415 \\
\hline 53 & only & 14 & 83,000 & 0 & 0 & 400 & $\mathbf{N} / \mathbf{A}$ & 240 & 55,000 & 400 \\
\hline 54 & Reflux ratio & 30 & 83,000 & 0 & 960 & 0 & 415 & 285 & 55,000 & 435 \\
\hline 55 & tests: top & 28 & 83,000 & 0 & 795 & 0 & 400 & 175 & 55,000 & 435 \\
\hline 56 & high pressure & 23 & 83,000 & 0 & 600 & 0 & 365 & 60 & 55,000 & 435 \\
\hline 57 & nozzles only & 16 & 83,000 & 0 & 400 & 0 & 270 & Dryout & 55,000 & 420 \\
\hline 58 & Reflux ratio & 32 & 83,000 & 2730 & 965 & 0 & 475 & 430 & 55,000 & 440 \\
\hline 59 & tests: nozzle & 32 & 83,000 & 2370 & 970 & 0 & 480 & 425 & 55,000 & 445 \\
\hline 60 & combinations & 32 & 83,000 & 2045 & 975 & 0 & 475 & 430 & 55,000 & 445 \\
\hline 61 & & 33 & 83,000 & 1520 & 975 & 0 & 470 & 420 & 55,000 & 440 \\
\hline 62 & & 34 & 83,000 & 2525 & 0 & 0 & 480 & 430 & 55,000 & 440 \\
\hline 63 & & 28 & 83,000 & 1285 & 885 & 0 & 480 & 425 & 55,000 & 440 \\
\hline 64 & & 34 & 83,000 & 1355 & 900 & 0 & 480 & 425 & 55,000 & 440 \\
\hline 65 & & 41 & 83,000 & 1410 & 930 & 0 & 475 & 415 & 55,000 & 450 \\
\hline 66 & & 41 & 83,000 & 1000 & 520 & 0 & 485 & 365 & 55,000 & 445 \\
\hline 67 & & 33 & 83,000 & 950 & 500 & 0 & 485 & 380 & 55,000 & 450 \\
\hline 68 & Repe atability & 25 & 83,000 & 910 & 0 & 475 & 485 & 420 & 55,000 & 435 \\
\hline \multirow[t]{2}{*}{69} & Surface & & & & & & & & & \\
\hline & conditioning & 0 & 83,000 & 0 & 0 & 0 & $\mathbf{N} / \mathbf{A}$ & $\mathbf{N} / \mathbf{A}$ & 55,000 & $\mathrm{~N} / \mathrm{A}$ \\
\hline 70 & Repe atability & 34 & 83,000 & 2515 & 0 & 0 & 490 & $\mathbf{N} / \mathbf{A}$ & 55,000 & 445 \\
\hline 71 & Condenser & 32 & 83,000 & 2490 & 0 & 0 & 490 & 550 & 55,000 & 445 \\
\hline 72 & test 8 & 31 & 83,000 & 2505 & $\mathbf{0}$ & 0 & 485 & 550 & 32,000 & 340 \\
\hline 73 & & 31 & 83,000 & 2510 & 0 & 0 & 485 & 545 & 66,000 & 485 \\
\hline 74 & & 45 & 83,000 & 2495 & 0 & 0 & 485 & 540 & 68,000 & 490 \\
\hline 75 & & 45 & 83,000 & 2490 & 0 & 0 & 480 & 540 & 58,000 & 455 \\
\hline 76 & & 44 & 83,000 & 2495 & 0 & 0 & 470 & 530 & a & $\mathbf{a}$ \\
\hline 77 & & 17 & 83,000 & 0 & 610 & 380 & 425 & 410 & 32,000 & 325 \\
\hline 78 & & 19 & 83,000 & 0 & 705 & 475 & 425 & 420 & 57,000 & 440 \\
\hline 79 & & 19 & 83,000 & 0 & 795 & 580 & 425 & 420 & 67,000 & 470 \\
\hline
\end{tabular}


Appendix A: Tabulation of Individual Test Runs (Cont'd)

\begin{tabular}{|c|c|c|c|c|c|c|c|c|c|c|}
\hline \multirow[b]{3}{*}{ Test } & \multirow[b]{3}{*}{ Description } & \multirow{3}{*}{$\begin{array}{l}\text { Heat } \\
\text { Duty } \\
\text { (MWt) }\end{array}$} & \multirow{3}{*}{$\begin{array}{l}\text { Warm } \\
\text { Water } \\
\text { Flow Rate } \\
\text { (gpm) }\end{array}$} & \multicolumn{3}{|c|}{ Ammonia Feed Rate ( $\mathrm{gpm})$} & \multicolumn{2}{|c|}{$U_{0}\left(B t u / h r \cdot f t^{2} \cdot{ }^{\circ} F\right)$} & \multirow{3}{*}{$\begin{array}{l}\text { Flow Rate } \\
\text { (gpm) }\end{array}$} & \multirow{3}{*}{$\left(\mathrm{Btu} / \mathrm{hr} \cdot \mathrm{ft}^{\mathrm{U}}{ }^{2 .}{ }^{\circ} \mathrm{F}\right)$} \\
\hline & & & & \multicolumn{2}{|c|}{ Top Nozzles } & \multirow{2}{*}{$\begin{array}{l}\text { Mid- } \\
\text { Plane }\end{array}$} & \multirow{2}{*}{$\begin{array}{l}\text { Plain } \\
\text { (upper) }\end{array}$} & \multirow{2}{*}{$\begin{array}{c}\text { Enhanced } \\
\text { (1 lower) }\end{array}$} & & \\
\hline & & & & Low-Pressure & High-Pressure & & & & & \\
\hline $\begin{array}{l}80 \\
81\end{array}$ & Repeatability & $\begin{array}{l}28 \\
24\end{array}$ & $\begin{array}{l}91,000 \\
76,000\end{array}$ & $\begin{array}{l}0 \\
0\end{array}$ & $\begin{array}{l}600 \\
595\end{array}$ & $\begin{array}{l}365 \\
450\end{array}$ & $\begin{array}{l}410 \\
395\end{array}$ & $\begin{array}{l}375 \\
430\end{array}$ & $\begin{array}{l}57,000 \\
44,000\end{array}$ & $\begin{array}{l}455 \\
400\end{array}$ \\
\hline 82 & Activation & 41 & 83,000 & 1005 & 0 & 0 & 460 & 235 & 44,000 & 395 \\
\hline 83 & test 8 & 21 & 83,000 & 1000 & 0 & 0 & 500 & 425 & 44,000 & 385 \\
\hline 84 & & 22 & 83,000 & 1000 & 0 & 0 & 495 & 495 & 44,000 & 395 \\
\hline 85 & & 41 & 83,000 & 1000 & 0 & 0 & 480 & 295 & 44,000 & 405 \\
\hline 86 & Miscellaneous & 38 & 83,000 & 800 & 0 & 0 & 590 & Dryout & 44,000 & 410 \\
\hline 87 & repe atability & 38 & 83,000 & 0 & 805 & 0 & 495 & Dryout & 44,000 & 405 \\
\hline 88 & and reflux & 22 & 91,000 & 0 & 490 & 0 & 232 & Dryout & 29,000 & 320 \\
\hline 89 & ratio tests & 17 & 57,000 & 1190 & 0 & 0 & 430 & 370 & 67,000 & 470 \\
\hline 90 & & 32 & 83,000 & 2560 & 0 & 920 & 485 & 605 & 44,000 & 405 \\
\hline 91 & & 32 & 83,000 & 3025 & 0 & 0 & 485 & 595 & 44,000 & 410 \\
\hline 92 & & 32 & 83,000 & 1490 & 0 & 0 & 485 & 565 & 44,000 & 410 \\
\hline 93 & & 32 & 83,000 & 950 & 0 & 650 & 480 & 555 & 44,000 & 410 \\
\hline 94 & & 29 & 83,000 & 0 & 800 & 810 & 415 & 530 & 44,000 & 410 \\
\hline 95 & & 13 & 79,000 & 0 & 810 & 810 & 445 & 490 & 44,000 & 380 \\
\hline
\end{tabular}

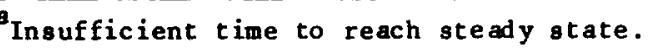

$\mathrm{N} / \mathrm{A}=$ Not applicable. 


\section{Distribution for ANL/OTEC-PS-10}

Internal:

E. Beckjord

T.R. Bump

E.J. Croke

J.B. Darby

J.D. Ditmars

J.J. Dzingel

B. Frost

A. P. Gavin

D. L. Hillis

A.B. Krisciunas
T. Kuzay

L.G. Lewis

J.J. Lorenz

K.S. Mac al

D. Mc Cown

C. B. Panchal

E.G. Pewi tt

G.F. Popper

J.J. Roberts

G.S. Rosenberg
N.F. Sather

A. Thomas (84)

D.T. Yung

R.S. Zeno

R.A. Zussman

ANL Contract File

ANL Libraries

ANL Patent Department

TIS Files (6)

\section{Externa1:}

U.S. Department of Energy Technical Information Center, for distribution per UC-64 (261)

Manager, U.S. Department of Energy Chicago Operations Office, (DOE-CH)

President, Argonne Universities Association

Energy and Enviromental Systems Division Review Committee:

E.E. Angino, University of Kansas

H.J. Barnett, Washington University

E.N. Castle, Resources for the Fut ure, Inc.

R. L. Clodius, National Association of State Universities and Land Grant Colleges

B.A. Egan, Enviromental Research and Technology, Inc.

N.C. Mullins, Indiana University

W.N. Poundstone, Consolidation Coal Co.

J.J. Stukel, University of Il linois

J.J. Wortman, North Carolina State University

Components Technology Division Review Committee:

A. Bishop, University of Pittsburgh

F.W. Buckman, Consumers Power Co.

R.A. Greenkorn, Purdue University

W.M. Jacobi, Westinghouse Electric Corp.

M.A. Schultz, North Palm Beach, Fla.

E.E. Ungar, Bolt Beranek and Newman, Inc.

$\mathrm{J}$. Weisman, University of Cincinnati

J.H. Anderson, Sea Solar Power, Inc., York, Penn.

K.J. Bel1, Oklahoma State University

A. Bergles, Iowa State University

Carnegie-Mel lon Un iversity

J. Fetkovich

R. Rothfus

A. Westerberg

J. Connel 1, Al fa-Laval Thermal, Inc., So. Deerfield, Md.

R.S. Dal rymple, Reynolds Metals, Richmond, Va.

G.J. Danek, Consultant, Annapolis, Md.

Dow Chemical Co., Freeport, Texas

W.D. Grimes

C.F. Schrieber 
EG\&G, Wal tham, Mass .

L. Hall

D. Fry

Electrotechnical Laboratory, Tokyo, Japan

T. Homma

T. Kajikawa

Energy Technology and Engineering Center, Rockwell International, Canoga Park, Calif.

A. Klein (12)

F. Poucher

H. Foust, Trane Co., LaCrosse, Wisc.

E.N. Ganic, University of Illinois at Chicago Circle

General Electric Co., Schenectady, N.Y.

R. Hind le

M.G. Olmsted

P.B. Pribis

J.H. Gibbons, U.S. Congress, Office of Technology Assessment, Washington, D.C.

L.W. Hallenger, Natural Energy Laboratory of Hawaii, Honolulu

R.N. Hazelwood, Global Marine Development, Inc., Kawaihae, Hawaii

W. Heronemus, University of Massachusetts, Amherst, Mass.

J. Hirshman, New York Institute of Technology, Danice, Fla.

International Nickel Company, Wrightsville Beach, N.C.

T.S. Lee

R. Lewi s

Johns Hopkins University/Applied Physics Laboratory

W. Avery

J. George

$\mathrm{J}$. Ke irsey

D. Richards

H. Kamogowa, Toshiba Corp., Kawasaki, Japan

D.E. Kash, University of Oklahoma

J. Knudsen, Oregon State University

Lawrence Berkeley Laboratory, Berkeley, Calif.

P. Wilde

V. Harms

A. Lavi, Energy Research and Development, Inc., Pittsburgh, Penn.

F.L. LaQue, Kingston, Ontario, Canada

B. Little, Naval Oceanic Research and Development Activity, Bay St. Louis, Miss.

Lockheed Missiles and Space Co., Sunnyvale, Calif.

R. Conti

R. Fuller

M. Leitner

F. Naef

W.L. Owens

L. Trimble

D. Lott, Naval Coastal Systems Center, Panama City, Fla.

P. Marto, Naval Post Graduate School, Monterey, Calif.

J. Maurer, Allegheny Lud lum Steel Corp., Brachenridge, Penn.

T. McGuinness, National Oceanic and Atmospheric Administration, Rockville, Md.

R.A. Meyer, OTEC Liaison, Chicago

L. Mims, Illinois Institute of Natural Resources, Chicago

R. Mitche11, Harvard University

J. Morse, University of Miami 
R.S.C. Munier, Tracor Marine, Kona, Hawaii

E.K. Noda, Noda Associates, Honolulu, Hawaii

Oak Ridge National Laboratory

F. Chen

R. Lyon

J. Miche1

R. Murphy

T.B. O'Neill, Civil Engineering Laboratory, Port Hueneme, Calif.

Rand Corp., Santa Monica, Calif.

C. Gaxley

R. $\mathrm{Pe} i$

K. Read, U.S. Naval Ac ad emy, Annapolis, Md .

Research Corp., University of Hawaii

W. Coops

W. Gorter

A. Rosenb 1 ad, Rosenb 1 ad Corp., Princeton, N.J.

C.M. Sabin, Geoscience, Ltd., Salena Beach, Calif.

M.D. Sands, Interstate Electronics Corp., Anaheim, Calif.

J. Sangiovani, United Technologies Research Center, E. Hart ford, Conn.

D. Sasscer, University of Puerto Rico

R. Scott, Gibbs \& Cox, Arlington, Va .

Solar Energy Research Institute, Golden, Colo.

T. Penny

D. Petty

S. Pohlman

B. Shelpuk

F. Spiehler, National Oceanic and Atmospheric Administration Data Buoy Office, National Space Technology Laboratory Station, Miss.

T.J. Summerson, Kaiser Al uminum, Pleasanton, Calif.

R.B. Teel, Teel \& Associates, Chatham, N.J.

TRW, Rendondo Beach, Calif.

J. Denton

R. Dougiass

E. Snyder

H. Uehara, Saga University, Japan

Union Carbide Corp., Tonawanda, N.Y.

A. Czikk

H. Fricke

P. O'Neill

U.S. Department of Energy, Oakl and, Calif.

J. Hartman

R. Salazar

U.S. Department of Energy, Washington, D.C.

E. Burcher (12)

C. Castellano

S. Gronich

L. Lewis

W. Richards

University of Hawaii

L.R. Berger

J. Larson-Basse

B. Liebert

J. Shupe

P. Yuen 
VSE, Al ex and ria, Va.

J. Sladky

J. Obradovich

E.T. Wanderer, Aluminum Co. of American, Alcoa Center, Penn.

R. Webb, Pennsylvania State University

Westinghouse Electric Corp., Philadelphia, Penn.

E. Barseness

J. Gertz

T.E. Little

P. Ritl and

D.C. White, Florida State University

R.E. Williams III, PRC Energy Analysis Co., Mclean, Va.

D. Wright, Rocketdyne Division, Rockwell International, Canoga Park, Calif.

J.F. Yampolsky, General Atomic Co., San Diego, Calif. 